\title{
DNA from lake sediments reveals the long-term dynamics and diversity of Synechococcus assemblages
}

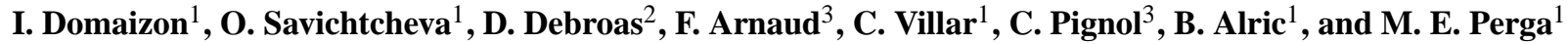 \\ ${ }^{1}$ INRA - UMR42 CARRTEL, Centre Alpin de Recherche sur les Réseaux Trophiques des Ecosystèmes Limniques - 74203 \\ Thonon-les-bains Cedex, France \\ 2Université Blaise Pascal Clermont, UMR CNRS 6023, Laboratoire "Microorganismes: Génome \& Environnement", 24, av. \\ des Landais - BP 80026-63171 Aubière Cedex, France \\ ${ }^{3}$ CNRS Université de Savoie, UMR5204, EDYTEM, 73379 Le Bourget du Lac, France
}

Correspondence to: I. Domaizon (isabelle.domaizon@thonon.inra.fr)

Received: 14 December 2012 - Published in Biogeosciences Discuss.: 12 February 2013

Revised: 29 April 2013 - Accepted: 9 May 2013 - Published: 14 June 2013

\begin{abstract}
While picocyanobacteria (PC) are important actors in carbon and nutrient cycles in aquatic systems, factors controlling their interannual dynamics and diversity are poorly known due to the general lack of long-term monitoring surveys. This study intended to fill this gap by applying a DNA-based paleolimnological approach to sediment records from a deep subalpine lake that has experienced dramatic changes in environmental conditions during the last century (eutrophication, re-oligotrophication and large-scale climate changes). In particular, we investigated the long-term (100 yr) diversity and dynamics of Synechococcus, PC that have presumably been affected by both the lake trophic status changes and global warming.

The lake's morphological and environmental conditions provided the ideal conditions for DNA preservation in the sediment archives. Generalised additive models applied to quantitative PCR (qPCR; quantitative Polymerase Chain Reaction) results highlighted that an increase in summer temperature could have a significant positive impact on the relative abundance of Synechococcus (fraction of Synechococcus in total cyanobacteria).

The diversity of Synechococcus in Lake Bourget was studied by phylogenetic analyses of the $16 \mathrm{~S}$ rRNA gene and the following internally transcribed spacer (ITS). Up to 23 different OTUs (based on 16S rRNA), which fell into various cosmopolitan or endemic clusters, were identified in samples from the past $100 \mathrm{yr}$. Moreover, the study of ITS revealed a higher diversity within the major $16 \mathrm{~S}$ rRNA-defined OTUs. Changes in PC diversity were related to the lake's trophic sta-
\end{abstract}

tus. Overall, qPCR and sequencing results showed that environmental changes (in temperature and phosphorus concentration) affected Synechococcus community dynamics and structure, translating into changes in genotype composition. These results also helped to re-evaluate the geographical distribution of some Synechococcus clusters.

Providing such novel insights into the long-term history of an important group of primary producers, this study illustrates the promising approach that consists in coupling molecular tools and paleolimnology to reconstruct a lake's biodiversity history.

\section{Introduction}

Picocyanobacteria (PC) can constitute the majority of the picophytoplankton, especially in large deep oligotrophic to mesotrophic lakes (Callieri and Pinolini, 1995; Personnic et al., 2009). Due to their ubiquity and abundance, freshwater PC (size fraction $0.2-2 \mu \mathrm{m}$ ) are of great importance to the carbon cycle of many lakes. Indeed, up to $70 \%$ of the annually fixed carbon is attributed to the picophytoplankton in ultra-oligotrophic waters (Caron et al., 1985; Callieri, 2008; Wilhelm et al., 2006). Owing to their small size and high surface-to-volume ratios, PC have relatively low phosphorus requirements and exhibit high nutrient acquisition efficiencies (Pitt et al., 2010). Such characteristics tend to favour PC proliferation over larger phytoplankters under nutrientlimiting conditions. Indeed, their relative contribution to the 
total phytoplankton has been shown to increase with decreasing trophic state (i.e. re-oligotrophication; Agawin et al., 2000). In addition, increased summer temperatures, combined with lowered soluble reactive phosphorus (SRP) levels, could provide PC an ecological advantage over other phytoplankton classes in various aquatic systems including lakes (Agawin et al., 2000; Collos et al,. 2009; Fu et al,. 2007). However, it is still difficult to disentangle the effects of reoligotrophication and concomitant global warming to the response of lacustrine PC, partly due to the lack of long-term monitoring data.

Previous studies highlighted that temperate European lakes support mainly phycoerythrin-rich Synechococcus cells, while phycocyanin-rich cells are rare (Katano et al., 2005; Callieri, 2008; Personnic et al., 2009). Although these Synechococcus-type cells contribute significantly to the total primary production of the lakes (Stockner et al., 2000), our current understanding of their ecology, diversity, distribution and taxonomy in fresh waters is still limited. In-depth understanding of the roles of biotic and abiotic interactions in controlling Synechococcus dynamics may yet not be achieved without considering the puzzle of Synechococcus diversity (genotypes and ecotypes). Phylogenetic studies have shown that PC described as Synechococcus type are polyphyletic (Robertson et al., 2001; Wilmotte and Herdman, 2001) and exhibit a substantial diversity in fresh waters with both cosmopolitan and endemic groups (Fernandez-Carazo et al., 2011; Jasser et al., 2011; Wu et al., 2010). Currently, studies on diversity and/or temporal dynamics of Synechococcustype cells have generally been performed at short timescales and/or in relation to seasonal patterns (Callieri and Stockner, 2002; Ivanikova et al., 2007; Becker et al., 2012). Only a single one-decade study (1986-1997) of the ecology of the autotrophic picoplankton in Lake Constance suggested shifts in the genetic composition of the PC population (Gaedke and Weisse, 1998; Postius and Ernst, 1999). Overall, the longterm dynamics of freshwater Synechococcus have been rarely documented because the picoplankton community has been only recently included in routine monitoring of lakes, and molecular analyses have not been commonly associated with multi-annual surveys. Therefore, data based on the coupling of long-term monitoring and molecular analyses is considerably lacking in addressing clade-specific picoplankton responses to environmental changes.

The lacustrine sediment record offers one of the best opportunities for studying how aquatic ecosystems function over long timescales (e.g. Battarbee, 2001), but its study has so far been restricted to the study of specific micro- and nano-phytoplanktonic groups that have diagnostic features that are preserved upon fossilisation (diatoms and chrystophytes). The recent development and application of molecular tools on DNA archived in lake sediments (Willerslev et al., 2007; Boere et al., 2011; Coolen et al., 2008; Epp et al., 2011) provide the opportunity to both complement the classical biological proxies (Coolen and Gibson, 2009) and to more exhaustively reconstruct past changes in the biodiversity and compositions of phytoplanktonic assemblages with high taxonomic resolution. Such long-term reconstructions may thereafter be used to identify the major environmental factors structuring the assemblages.

In this study, the long-term (over $100 \mathrm{yr}$ ) diversity and dynamics of Synechococcus were investigated by the analysis of DNA preserved in the sediment of Lake Bourget, a large deep subalpine lake. Dramatic changes in the lake's environmental conditions over the last century, i.e. eutrophication between the late 1930s and early 1990s (Giguet-Covex et al., 2010) and an ongoing re-oligotrophication within a context of climate warming (Dokulil et al., 2006; Anneville et al., 2007; Gerdeaux, 2011), were assumed to impact Synechococcus population abundance and structure, eventually translating into changes in its genotype composition. Therefore, the objective of this study was threefold. The first aim was to assess the dynamics of Synechococcus(i.e. abundance relative to total cyanobacteria), applying a quantitative polymerase chain reaction technique (qPCR) along a sediment core (37 samples covering the last $100 \mathrm{yr}$ ). Secondly, the diversity of Synechococcus spp. was investigated as well as the potential changes in its phylogenetic composition over a long-term time scale. Diversity was examined at 8 different time periods (corresponding to the distinct trophic status states of the lake over the past $100 \mathrm{yr}$ ), using phylogenetic analyses of 16S rRNA gene and internally transcribed spacer (ITS) sequences. Finally, local and regional environmental forces (here, phosphorus concentration vs. temperature) responsible for shifts in Synechococcus diversity and structure were identified using multivariate analyses.

\section{Material and methods}

\subsection{Study site}

Lake Bourget $\left(45^{\circ} 45^{\prime} \mathrm{N}, 5^{\circ} 52^{\prime} \mathrm{E}\right)$ is a large $(18 \mathrm{~km}$ long, $2.8 \mathrm{~km}$ wide, $45 \mathrm{~km}^{2}$ ), deep (maximum depth: $145 \mathrm{~m}$ ), hardwater monomictic lake located at the northwestern edge of the French Alps at $232 \mathrm{~m}$ above sea level. The trophic status history of Lake Bourget has been documented in recent monitoring surveys and paleolimnological studies (Millet et al., 2010; Giguet-Covex et al., 2010; Alric, 2012). Initially described as an oligotrophic system in the 1930s, the lake suffered from eutrophication due to industrial effluents, domestic sewage and cultural practices (Giguet-Covex et al., 2010). Algal blooms were first observed in the early 1950s (Laurent, 1970). In the mid-1970s, limnological monitoring indicated total phosphorus (TP) concentrations that reached $120 \mu \mathrm{g} \mathrm{L}^{-1}$ at winter overturn. After diversion of the main wastewater discharge at the beginning of the 1980s, TP winter concentrations gradually dropped to $17 \mu \mathrm{g} \mathrm{L}{ }^{-1}$ in 2009 (INRA long-term lake observatory). Moreover, Lake Bourget has been experiencing significant climatic changes over the 
last decades. Previous analysis of the HISTALP (historical instrumental climatological surface time series of the greater alpine region) datasets (http://www.zamg.ac.at/histalp) has shown that annual and seasonal air temperatures exhibited a common and significant increasing trend beginning in the late 1980s (Auer et al., 2007). Between 1986 and 2009, mean annual air temperature at Lake Bourget increased by more than $1^{\circ} \mathrm{C}$ (Alric, 2012).

\subsection{Core sampling and dating}

Several sediment cores (diam: $9 \mathrm{~cm}$ ) were retrieved in April 2009 at the deepest part of the northern basin of Lake Bourget $\left(45^{\circ} 45^{\prime} 20.04^{\prime \prime} \mathrm{N}, 5^{\circ} 51^{\prime} 19.92^{\prime \prime} \mathrm{E}, 145 \mathrm{~m}\right.$ water depth) using a UWITEC gravity corer. One core (LDB04-P1) was used as a reference for dating using radiometric methods $\left({ }^{210} \mathrm{~Pb},{ }^{226} \mathrm{Ra},{ }^{137} \mathrm{Cs}\right.$ and ${ }^{241} \mathrm{Am}$ activities) and counting of annual laminations, which provided accurate chronologies for high-resolution sampling in both cores (see details in Appendix A). Basic elemental measurements were also performed on the reference core, such as measurements of total organic carbon content (TOC) using Rock-Eval pyrolysis (Espitalié et al., 1985; Disnar et al., 2003).

The sediment core, dedicated to molecular analysis (and pigment analysis) (LDB09-P2) was sampled according to its annual laminations (see below for sampling precautions) and correlated to the reference core using lithological tie points and lamina counting performed on both the reference and working core (Appendix A, Zolitschka, 2003). Such high temporal resolution and accuracy were required to integrate instrumental and paleo-data from multiple cores.

\subsection{Molecular analysis}

All laboratory procedures were carried out considering strict precautions to ensure authenticity of the results. Isolation of the core samples was carried out in a specific laboratory physically separated from the usual molecular biology laboratory. Due to the risk of contamination of the sediment samples by modern DNA, special laboratory precautions and rigorous controls against contamination were applied to all steps: (i) separated stations were used for sediment sampling, DNA extractions, PCR mix preparation and post-PCR manipulations; (ii) gloves, masks and sterile disposable labware were used during sediment sampling; (iii) molecular analyses (extraction, PCR mix assembly and cloning) were performed in dedicated sterile workstations (laminar flow UV-hoods) that combined ISO 5 (FS209E) Class 100 clean air environments with UV light sterilisation; (iv) a restricted number of samples were manipulated simultaneously in each analysis (e.g. no more than 4 samples at a time for DNA extraction procedures); and (v) negative controls were used (blanks with sterile water instead of sample) at all steps (i.e. sampling of the core, DNA extraction and preparation of PCR mixes) to identify aerosolised contaminants that may have entered samples and/or reagent tubes.

\subsubsection{Subsampling for molecular analyses}

Only the centre of the core was kept for molecular analysis because it was preserved from any contamination due to contact with the plastic liner at the periphery. The sampling interval was chosen to fit a complete number (1-3) of lamina triplets. Thirty-seven slices were sampled along the first $40 \mathrm{~cm}$ of the sediment core. For each sediment sample (BF1BF37), an aliquot of $10 \mathrm{~g}$ of wet sediment was dried at $50^{\circ} \mathrm{C}$ and weighed to estimate the dry weight and a second aliquot of $5 \mathrm{~g}$ of wet sediment was preserved for pigment analysis. The rest of the sample was subjected to molecular analysis (kept at $-80^{\circ} \mathrm{C}$ until analysis).

\subsubsection{DNA extraction from sediment samples}

Two sets of DNA extractions from identical sediment samples were performed in different physically isolated laboratories to control contamination by modern DNA. For each set of DNA extractions, genomic DNA was extracted from 3 subsamples of $1 \mathrm{~g}$ of wet sediment each to avoid heterogeneity using the UltraClean Soil DNA Isolation Kit according to the manufacturer's instructions (Mobio, Carlsbad, CA, USA). The 3 DNA extracts were thereafter pooled, and the total DNA concentration was measured using the Quant-iT PicoGreen kit (Invitrogen) and a Rotor Gene 3000 qPCR cycler with software version 6.0 (Corbett Research, Mortlake, NSW, Australia). Quantification according to lambda DNA standards (Invitrogen) was performed in triplicate. The two sets of DNA were stored at $-20^{\circ} \mathrm{C}$ until further analysis.

\subsubsection{Quantitative PCR assays}

Two types of qPCR chemistries were applied in our study. A SYBR Green assay, of which the specificity for cyanobacteria has been previously validated for sediment samples (Savichtcheva et al., 2011), was used to quantify total cyanobacteria, and the Taq nuclease assay (TNA) was applied to quantify Synechococcus spp. As a validation step, interlaboratory comparison of the quantification results were previously performed in two different laboratories in Thonon-les-Bains and Clermont-Ferrand using 30 sediment samples selected along the core. Samples were analysed in the laboratories of the two partners to ensure the reliability of qPCR assays and to exclude the possibility of contamination by modern DNA (results indicating a highly significant correlation $(p<0.001)$ are fully presented in Savichtcheva et al., 2013).

All amplifications were performed in triplicate using a Rotor Gene 3000 qPCR cycler with software version 6.0 (Corbett Research, Mortlake, NSW, Australia). QPCR assays were performed for the 37 samples (BF1-BF37) covering the period 1909-2009. Table 1 describes the ampli- 
Table 1. Size of amplicons, oligonucleotide primers and TaqMan probes used for PCR and qPCR to target total cyanobacteria and Synechococcus populations. $F=$ forward, $R=$ reverse, $\mathrm{Tp}=$ Taq man probe, $R=$ reporter, $Q=$ quencher.

Target positions of PCR and qPCR primers and probes in the ribosomal operon of Synechococcus spp. are illustrated: the arrows indicate the $5^{\prime}$ to $3^{\prime}$ orientation of the oligonucleotides.

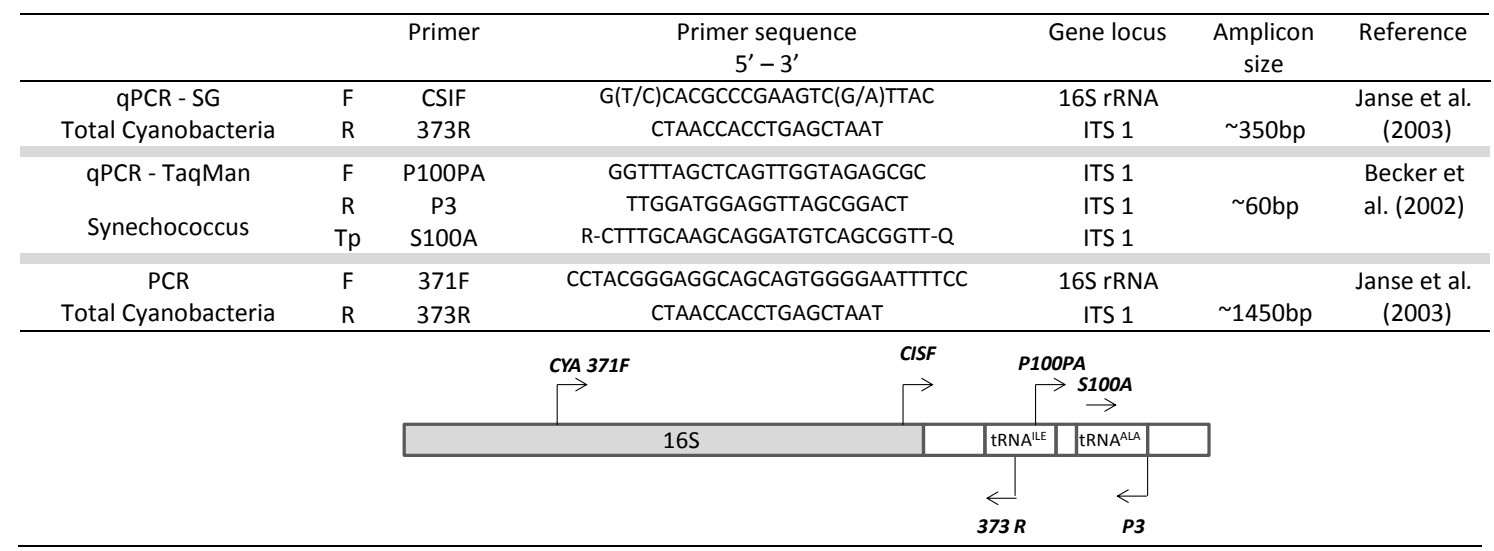

cons' size and target positions of qPCR primers and probes used in this study to target cyanobacteria or specifically Synechococcus spp.

For quantification of total cyanobacteria, forward CSIF $\left(5^{\prime}-\mathrm{G}(\mathrm{T} / \mathrm{C}) \mathrm{CACGCCCGAAGTC}(\mathrm{G} / \mathrm{A}) \mathrm{TTAC}-3^{\prime}\right)$ and reverse 373R (5'-CTAACCACCTGAGCTAAT- $\left.3^{\prime}\right)$ primers targeting the rRNA-ITS region were used (Janse et al., 2003; Savichtcheva et al., 2011). QPCR reactions were performed in a $25-\mu \mathrm{L}$ volume containing $12.5 \mu \mathrm{L}$ of $2 \times$ QuantiTect SYBR Green PCR Master Mix (Qiagen), $500 \mathrm{nM}$ of each forward and reverse primer (Biomers), and $2 \mu \mathrm{L}$ of DNA. The qPCR program consisted of an initial polymerase activation step $\left(95^{\circ} \mathrm{C}\right.$ for $15 \mathrm{~min}$ ), followed by 40 cycles of denaturation at $94^{\circ} \mathrm{C}$ for $60 \mathrm{~s}$, annealing at $60^{\circ} \mathrm{C}$ for $60 \mathrm{~s}$, extension at $72^{\circ} \mathrm{C}$ for $60 \mathrm{~s}$. As a post-PCR analysis, the qPCR program was followed by a melting-curve determination step (from $70^{\circ} \mathrm{C}$ to $95^{\circ} \mathrm{C}$ at a transition rate of $1{ }^{\circ} \mathrm{C}$ every $5 \mathrm{~s}$ ) to assess the specificity of the amplification. Moreover, all qPCR products from the SG-rRNA-ITS assays were analysed for nonspecific PCR amplification by electrophoresis migration on $2 \%$ agarose gel, for $99 \mathrm{~min}$ at $50 \mathrm{~V}$ (Scovhus et al., 2004).

For quantification of Synechococcus, a TNA targeting the 16S-23S internally transcribed spacer (ITS1) sequence was applied (Becker et al., 2002). The specificity of this assay was confirmed using Synechococcus and non-Synechococcus axenic strains available from the Thonon Culture Collection (TCC; INRA, France; http://www6.inra.fr/carrtel-collection eng/). The TNA reaction mix $(25 \mu \mathrm{L})$ contained $12.5 \mu \mathrm{L}$ of Rotor Gene multiplex PCR master mix (Qiagen), $300 \mathrm{nM}$ of each forward (P100PA) and reverse (P3) primers (Biomers), $200 \mathrm{nM}$ TaqMan probe (S100A, dually labeled with 6carboxyfluorescein, 6-FAM, at the $5^{\prime}$ ends and black hole quencher-1, BHQ-1, at the $3^{\prime}$ ends), and $2 \mu \mathrm{L}$ of DNA. The qPCR program consisted of an initial polymerase activation step $\left(95^{\circ} \mathrm{C}\right.$ for 5 minutes), followed by 40 cycles of two-step PCR consisting of a denaturation at $95^{\circ} \mathrm{C}$ for $15 \mathrm{~s}$ and subsequent annealing and elongation steps at $60^{\circ} \mathrm{C}$ for $15 \mathrm{~s}$.

Ten-fold dilution standards were prepared from genomic DNAs (gDNAs) of pure cultures, ranging from 2.5 to $2.5 \times 10^{-5} \mathrm{ng}$ gDNA $\mu \mathrm{L}^{-1}$ to create two distinct standard curves for SYBR-Green-based qPCR and TNA. The 16S rRNA and ITS1 copy numbers of cyanobacterial standard strains were calculated as described previously (Savichtcheva et al., 2011), assuming average 16S rRNA gene copy numbers of 3 and 3.25 for total cyanobacteria and Synechococcus, respectively (Fogel et al., 1999; Panieri et al., 2010; Becker et al., 2002). The approximate genome size of the Synechococcus spp. was determined to be $3.0 \mathrm{Mb}$ (Becker et al., 2002), and the average size of a cyanobacterial genome $(4.2 \mathrm{Mb})$ was used to estimate their total counts (http://www.ncbi.nlm.nih.gov/genomes/lproks. cgi?view=1) (Vaitomaa et al., 2003). It was calculated that $25 \mathrm{ng}$ of each gDNA standard corresponded to an average of $7.58 \times 10^{6}$ and $5.48 \times 10^{6}$ cells for Synechococcus and total cyanobacteria, respectively, according to the equation:

Number of copies per microlitre $=$ DNA concentration $\left(\mu \mathrm{g} \mu \mathrm{L}^{-1}\right) \times 10^{6}\left(\mathrm{pg} \mathrm{\mu g}^{-1}\right) \times(1 \mathrm{pmol} / 660 \mathrm{pg} \times$ genome size, bp) $\times 6.022 \times 10^{23}\left(\right.$ copies mol $\left.{ }^{-1}\right) \times 10^{-12}\left(\mathrm{~mol} \mathrm{pmol}^{-1}\right)$.

$\mathrm{Cq}$ values (instead of $\mathrm{Ct}$, according to MIQE guidelines, Bustin et al., 2009) of the sediment samples were determined for both the TNA and SYBR Green assays according to the standard curve for each qPCR assay, adjusted to the $\mathrm{Cq}$ value of the appropriate $10^{-4}$ or $10^{-5} \mathrm{~g}$ DNA standard used as the positive control in each run. 


\subsubsection{S-ITS1 rRNA genetic libraries (PCR and cloning/sequencing)}

Sequence data for the 16S rRNA gene and ITS1 region (approximately $1500 \mathrm{bp}$ ) were obtained for the sediment samples BF1 (2008-2009), BF3 (2000-2001), BF10 (19911993), BF12 (1987-1988), BF15 (1981-1983), BF20 (19721973), BF24 (1956-1960), and BF27 (1951-1952). These sediment layers were chosen to compare distinct regions that might correspond to the different trophic periods of the lake (oligotrophic to eutrophic).

Previous tests performed to assess the level of DNA preservation (DNA fragment quality/integrity) showed that the DNA was remarkably well preserved (at least from the 8 sediment layers we considered here, i.e. from the 1950s). It was thus possible to amplify long DNA fragments (1500 bp). Therefore, we performed the sequencing analyses targeting the $16 \mathrm{~S}$ rRNA-ITS region (approximately $1500 \mathrm{bp}$ ), which enables analyses of long DNA sequences and relevant phylogenetic analyses. Table 1 describes the amplicons' size and target positions of PCR primers used in this study to target cyanobacteria.

PCR amplification of cyanobacterial 16S rRNA-ITS region (Janse et al., 2003) was performed in a volume of $50 \mu \mathrm{L}$ containing up to $50 \mathrm{ng}$ of DNA, $5 \mu \mathrm{L}$ of $10 \times$ PCR buffer (Bioline), $500 \mathrm{nM}$ of each forward, CYA371F (5'CCTACGGGAGGCAGCAGTGGGGAATTTTCC- $3^{\prime}$ ), and reverse, 373R (5'-CTAACCACCTGAGCTAAT-3'), primers (Biomers), $1.2 \mathrm{mM}$ of $\mathrm{MgCl}_{2}$ (Bioline), $1 \mathrm{U}$ of Taq DNA polymerase (Bioline), deoxynucleoside triphosphates (200 $\mu \mathrm{M}$ each, Bioline), and $1 \mathrm{mg} \mathrm{ml}^{-1}$ bovine serum albumin (BSA, Sigma). The PCR program included an initial denaturation at $94{ }^{\circ} \mathrm{C}$ for $5 \mathrm{~min}$, followed by 30 cycles at $94^{\circ} \mathrm{C}$ for $1 \mathrm{~min}$, at an annealing temperature of $60^{\circ} \mathrm{C}$ for $1 \mathrm{~min}$, elongation at $72^{\circ} \mathrm{C}$ for $1 \mathrm{~min}$, and a final extension step at $72^{\circ} \mathrm{C}$ for $10 \mathrm{~min}$. All PCR reactions were performed using a TProfessional Basic Gradient Thermocycler (Biometra). The amplification products were used for the construction of clone libraries using a TOPO TA cloning kit (Invitrogen, Carlsbad, CA) with PCR vector 2.1 according to the manufacturer's instructions. The amplification products of 96 cyanobacterial clones were sequenced (Beckman Coulter Genomics Inc.) for each of the 8 sediment samples (without pre-screening by RFLP method).

\subsubsection{Post-sequencing and phylogenetic analysis}

CodonCode Aligner software (version 3.7.1, CodonCode Corp., Dedham, MA, USA) was used to assemble contig sequences from the forward and reverse reads. The resulting contig sequences were separated into 16S rRNA genes and ITS1 regions for further analyses. The partial 16S rRNA sequences were aligned using the CLUSTAL $\mathrm{W}$ procedure (Thompson et al., 1994) using the BioEdit Sequence Alignment Editor (version 7.0.5.3).
The sequences were screened for potential chimeric structures using the Bellerophon program (http://comp-bio.anu. edu.au/bellerophon/bellerophon.pl) (Huber et al., 2004).

$16 S$ analysis. DOTUR was used to determine operational taxonomic units (OTUs) in the 16S rRNA sequence data (Schloss and Handelsman, 2005) with a cut-off equal to $97 \%$. To determine the first phylogenetic affiliation, each OTU was compared with sequences available in databases using the alignment search tool (BLASTN) from the National Centre for Biotechnology Information and the Ribosomal Database Project (Altschul et al., 1990). We retrieved the closest sequences identified in this way to include them in an alignment containing sequences from the closest cultivated members and some representative sequences of the major taxa. Sequences were re-aligned, and the resulting multiple alignment was checked and corrected manually. A phylogenetic tree was then constructed by the maximum likelihood (ML) method using MEGA5 software (Tamura et al., 2011). The ML analyses were carried out using the optimum model of sequence evolution selected according to the Akaike information criterion (AIC); as a result, the GTR $+\mathrm{G}+\mathrm{I}$ model of nucleotide substitution was used. Bootstrap proportions were inferred using 1000 replicates. The resulting tree was pruned to retain sequences representative of each OTU and its closest relatives. The ML phylogenetic tree obtained from the partial 16S rRNA gene sequences (1100 bp alignment) was confirmed by a neighbour-joining analysis using the correction of Jukes and Cantor (1969) with 1000 bootstraps. Clusters were identified based on the following criteria: (i) each contains sequences from at least 2 different samples (sediment or other origins), (ii) each is a monophyletic group supported by the two tree constructions, and (iii) the bootstrap values are higher than $60 \%$. By using these criteria, the percentage similarity among environmental sequences belonging to the same cluster was greater than $97 \%$.

The relative distribution of OTUs in the library was used to calculate coverage values (Good's coverage) (Hughes et al., 2001) and the non-parametric richness estimators Chao 1 (Chao, 1984) and ACE (Chao and Lee, 1992), which are the most appropriate for microbial clone libraries (Kemp and Aller, 2004).

The sequences reported in this paper have been deposited into GenBank (accession numbers: JX456478-JX456528).

ITS1 analysis. The ITS1 sequences were analysed to assess the homogeneity of ITS1 sequences within the same OTU. The ITS sequences were analysed by similarity searches using the BLAST program and then aligned on the basis of conserved domains (Iteman et al., 2000) using the BioEdit aligner. The ITS sequences were grouped into "ITS types", which are groups of sequences that can be meaningfully aligned (Wilmotte, 1994, from Fernandez-Carazo et al., 2011) sharing at least $80 \%$ pairwise identities. 


\subsection{Cultured sample collection for modern Synechococcus spp.}

A total of 8 Synechococcus spp. strains were used as references for modern Synechococcus isolated from 3 deep subalpine lakes (Bourget, Geneva, Annecy) in 2005. Strains (TCC 206, 217, 218, 222, 31, 32, 33, 34) were obtained from the Thonon Culture Collection (TCC). All strains were grown under sterile conditions in BG11 medium (Rippka, 1998) under continuous light $(20 \mu \mathrm{mol}$ photon (or quanta) $\mathrm{m}^{-2} \mathrm{~s}^{-1}$ ) at $20 \pm 2{ }^{\circ} \mathrm{C}$. Genomic DNAs (gDNAs) were extracted using the DNA extraction protocol for GenElute LPA (linear polyacrylamide) modified by Jardillier et al. (2010). Modifications included the addition of $1 \mu \mathrm{l}$ of GenElute LPA (Sigma-Aldrich, Inc.) to aid in DNA recovery. Procedures for PCR amplification, cloning, sequencing and post-sequencing analyses were similar to those described above for sediment samples.

\subsection{Statistical analysis}

\subsubsection{Statistics applied to qPCR counts}

We aimed to evaluate the role of environmental factors on the long-term dynamics of Synechococcus. Amongst these factors, long-term changes in lake total phosphorus concentrations (as reconstructed between 1880 and 2009 using a diatom-inferred transfer function, Berthon et al, see appendix $\mathrm{B}$ for details) and climate variability (air temperature anomalies between 1880 and 2009 extracted from the gridded HISTALP dataset, Auer et al., 2007) are likely to exert strong structuring effects. A generalised additive model (GAM, Hastie and Tibshirani, 1986) was used to investigate the relationships between the temporal variation of Synechococcus relative abundance (as revealed by the ratios of Synechococcus to total cyanobacteria qPCR counts) and these specific external forcings, as well as to separate and quantify their influences. GAM is a semi-parametric regression technique with the main advantage of not being tied to a particular functional relationship (i.e. linearity) and to be less restrictive than other methods in assumptions about the underlying statistical distribution of the data. In GAM, predictors (covariates) are assumed to affect the response variable through additive sums of unspecified smooth functions. The GAM parameterisation and adaptation to paleoecological data were performed following Simpson and Anderson's (2009) technical recommendations. $P$ values (from likelihood ratio tests) were used to evaluate the significance of each additional factor, while the AIC and adjusted coefficients of determination $\left(R^{2}\right.$ adjust) were used to select the best model. We allowed for autocorrelation in the residuals by introducing a continuous-time first-order autoregression process [CAR(1)] to the model because the data were a time series. The feature selection process was based on a shrinkage method using the commonly used stepwise procedure, but the results were also checked by using a double-penalty approach (Marra and Wood, 2011). This statistical tool is effective for dealing with both linear and non-linear relationships between the response and the set of explanatory variables and to elucidate questions of the extent to which and when interacting factors play significant roles (e.g. Dong et al., 2011; Tao et al., 2012). In our study, diatom-inferred phosphorus concentrations and air temperature anomalies were introduced as the predictor variables in the model, while Synechococcus quantifications (inferred from qPCR results) were considered as the response variable. GAM was performed using $\mathrm{R}$ statistical software ( $\mathrm{R}$ development core team, 2008) with the mgcv package (Wood, 2006).

\subsubsection{Statistics applied to phylogenetic information}

From the sequencing results, the beta-diversity was studied by the UniFrac method (http://bmf2.colorado.edu/unifrac/ index.psp, Lozupone and Knight, 2005). UniFrac measures the phylogenetic distance between sets of taxa in a phylogenetic tree (unweighted UniFrac measures the distance between two communities by calculating the fraction of the branch length in a phylogenetic tree that leads to descendants in either, but not both, of the two communities). To compare PC communities from the 8 genetic libraries, unweighted UniFrac metrics were used to perform a principal coordinate analysis (PCA). In addition, we extracted coordinates on the PCA axes to apply a regression between those coordinates and environmental parameters (temperature and phosphorus) to evaluate potential correlations. The P-value matrix (comparison of each sample to each other sample) calculation was also performed using the UniFrac metrics.

To estimate the genetic differentiation of Synechococcus (from 16SrRNA OTUs and from ITS types) between different sediment layers, we calculated Nei's Gst coefficient of differentiation (equivalent to Wright's Fst) (Nei, 1987) using MEGA5 software (Tamura et al., 2011). We calculated each parwise Gst values to look for genetic differentiation between the 8 different analyzed layers (BF1, BF 3, BF10, BF12, BF 15, BF 20, BF 24, BF 27).

\section{Results}

\subsection{Organic matter and total phosphorus inferred from sediments}

Total organic carbon varied over the last century from $0.60 \%$ to $2.97 \%$ of total sediment dry weight. A shift is observed in the mid-1940s when TOC increased (Fig. 1). The rise in phosphorus concentration in the water was concomitant with the shift in TOC values and is clearly marked after the mid-1950s. TOC remained high from the late 1950s to the most recent time period, in spite of the lake's trophic status decreasing from eutrophic to oligo-mesotrophic during the latest $20 \mathrm{yr}$, as illustrated by the diatom-inferred 
temporal profile of phosphorus concentration (Appendix B, Berthon et al., 2013) (Fig. 1).

\subsection{Total cyanobacteria and Synechococcus quantifica- tion as revealed by qPCR}

The highest levels of total cyanobacteria and Synechococcus were found in the most superficial sediment layer (BF1) with up to $5.13 \times 10^{6}\left( \pm 0.110 \times 10^{6}\right)$ and $0.15 \times 10^{6}$ $\left( \pm 0.004 \times 10^{6}\right)$ cells $\mathrm{g}^{-1}$ of dry sediment, respectively. This upper layer corresponds to the most recent deposit (2008-2009) and may contain fresh material that had not yet undergone diagenesis. Because they may not purely represent archived DNA, the results from the first layer were therefore excluded from the descriptions of temporal dynamics of cyanobacteria and Synechococcus.

The amounts of total cyanobacteria and Synechococcus retrieved from the sediments globally mirrored the lake's trophic history. They were generally low and stable when the lake was oligotrophic from 1920 to 1955 (Fig. 2). From the mid-1950s, when the lake's trophic status dramatically increased, the amount of DNA attributed to total cyanobacteria increased, with the highest levels recorded in the 1980s and the late 1990s. Synechococcus-derived DNA tended to increase beginning in the early 1960s, the highest amounts of Synechococcus being recorded between 1975 and 1999. The recent years (2000-2007), corresponding to lake reoligotrophication, were marked by a decrease in the signal for total cyanobacteria with a simultaneous increase in the relative proportion of the Synechococcus community (Fig. 2).

Before the 1940s, the absence of annual laminations and low TOC in the sediment indicated that the lake bottom was oxic; thus the low direct counts obtained by qPCR in the sediment dated from before 1940s could reflect less efficient preservation in the upper layers rather than real changes in cyanobacterial abundance over time. To account for the different DNA preservation levels within the sediment core, relative counts (i.e. the ratios of Synechococcus counts to total cyanobacterial counts), instead of absolute counts, were calculated and introduced as the response variable in the GAM model. The parameters included in the model (lake trophic status (i.e. P concentrations) and temperature anomalies) accounted for $44.2 \%$ of the variation in the Synechococcus/total cyanobacteria ratio. The GAM results showed that air temperature significantly affected $(p<0.001)$ the variations in Synechococcus relative abundance (Table 2). The fitted smooth function obtained suggested that when summer temperature anomalies were higher than $+1^{\circ} \mathrm{C}$, a positive effect was observed on the proportion of Synechococcus (Fig. 3). The contribution of the summer air temperature was significant mostly during the last $15 \mathrm{yr}$ and occasionally during the 1940s and early 1950s.

\subsection{Cyanobacterial and Synechococcus richness based on the $16 \mathrm{~S}$ rRNA gene region}

The primers used for the sequencing analyses are not specific for Synechococcus, rather they target the whole cyanobacterial group. However, the Synechococcus community largely dominates in the clone libraries, representing 400 of the 610 sequences obtained for the 8 sediment samples analysed. Phylogenetic analyses of the sequences obtained from the sedimentary record suggested a large diversity of Synechococcus in Lake Bourget. These 400 sequences were grouped into 23 OTUs (based on the 16S rRNA gene; Fig. 4), which represents $37 \%$ of the whole cyanobacterial diversity detected in the Lake Bourget sediment (8 sediment layers within the period 1950-2009). Other OTUs were affiliated with various genera: Pleurocapsa, Cyanothece, Aphanocapsa, Leptolyngbya, Microcystis, Chroococcidiopsis, Microcoleus, Chroococcus, Synechocystis, Nostoc, Anabaena and Planktothrix, as described in Savichtcheva et al. (2013).

Different layers were chosen for phylogenetic analyses to represent the different phases of the lake's trophic history: BF27 and BF24 (1951-1952 and 1956-1960, respectively) corresponded to the transition from oligotrophic to eutrophic situations. The recent years (BF1 and BF3, i.e. 2008-2009 and 2000-2001, respectively) were characterised by a return to oligo-mesotrophic status, while the 4 layers chosen from the 1970s to the 1990s (BF10: 1991-1993, BF12: 19871988, BF15: 1981-1982, BF20: 1972-1973) corresponded to the period of eutrophication, which was especially pronounced in 1987-1988.

Depending upon the sediment layer, the number of OTUs affiliated with Synechococcus varied from 4 (1956-1960) to 10 (1972-1973), and the richness estimators SChao and SAce varied from 4 to 17 , and 5 to 18 , respectively (Table 3). No link was detected between the variation in the richness estimators and the lake's trophic status. Rarefaction curve analyses performed for Synechococcus sequences showed a rather good coverage of the richness especially for the layer BF24; however, the richness was not fully covered and we assume that the real diversity is probably higher (Supplement Fig. S1).

\subsection{Phylogenetic analysis of Synechococcus phylotypes based on the 16S rRNA gene region}

Sequences retrieved from the sedimentary record were of good quality, and most of them matched perfectly with sequences from various Synechococcus species isolated from different lakes worldwide. A phylogenetic tree was constructed from an alignment of 106 sequences (among which 59 sequences were representative of the OTUs in the Lake Bourget sediment), including 8 Synechococcus isolates from 3 deep subalpine lakes (Thonon culture collection) and 39 reference sequences from other lakes. 

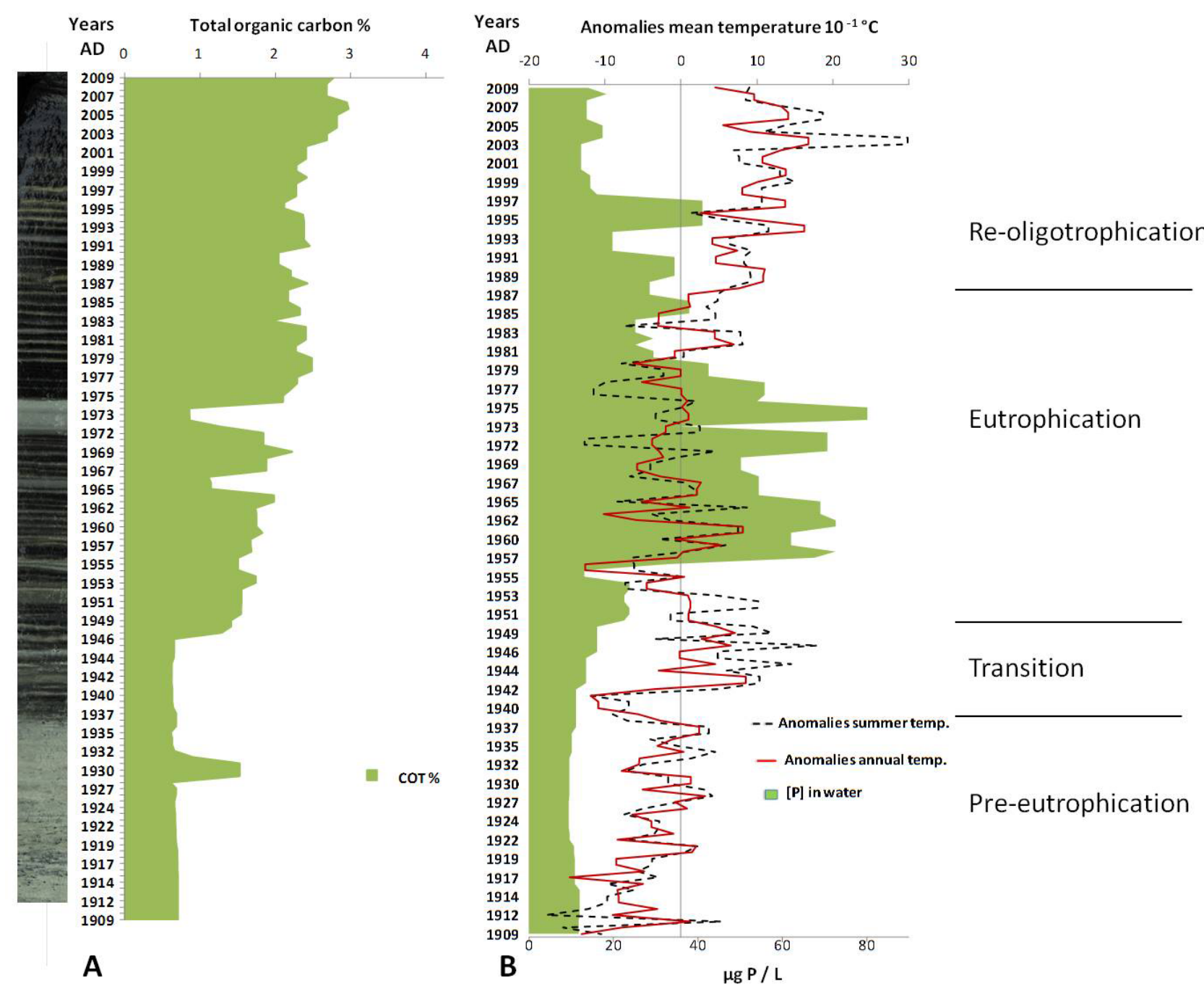

Fig. 1. Profile A presents the organic geochemistry diagram from sediment core: TOC (total organic carbon) in percent of dry sediment (1909-2009). A photograph of the core is provided. Profile B presents Phosphorus the concentration (in water) reconstructed over the study time using a diatom-transfer function; the evolution of temperature as revealed by anomalies to 20th century mean temperature; the annual average and the summer average $\left(10^{-1}{ }^{\circ} \mathrm{C}\right)$ are presented.

Most of the sequences derived from the sediment samples fell into previously described or novel clades (Fig. 4). Based on the number of sequences affiliated with each OTU, six dominant OTUs were identified (OTU b2, b7, b8, b19, b20 and b23). Of these OTUs, two belonged to Subalpine clusters I and II. Sequences from these OTUs were retrieved from all layers (1951-2009) except BF1 (2008-2009), which had no sequences from Subalpine cluster I. One of the dominant OTUs (in terms of number of sequences and presence in all sediment layers) grouped within cosmopolitan Group A. Two other major OTUs (OTUb7 and OTUb8) were part of Group E (previously described by Crosbie et al., 2003; Ernst et al., 2003). It is worth mentioning that OTUb7 was retrieved only in three layers corresponding to the eutrophi- cation period (1981-1993), while the presence OTUb8 was detected in all of the other layers.

OTUb20 (represented by 24 sequences) showed high similarity $(99.4 \%)$ to a strain isolated from Lake Champlain (Vermont, USA; accession number: HQ687069). Two strains from the Thonon culture collection (TCC 222 and TCC 218 isolated in 2005 from lakes Annecy and Bourget, respectively) were also affiliated with the same group, together with sequences originating from various freshwater systems (i.e. Rimov reservoir, Czech Republic and Lake 124, UK). The bootstrap value is $90 \%$ for this cosmopolitan group that we propose to name Group N (similarities between pairs of the sequences in group $\mathrm{N}$ varied from 99.2 to $100 \%$ ).

The rare OTUb4 (9 sequences found in layers 1987-1988 and 1972-1973) clustered with a novel group composed of 

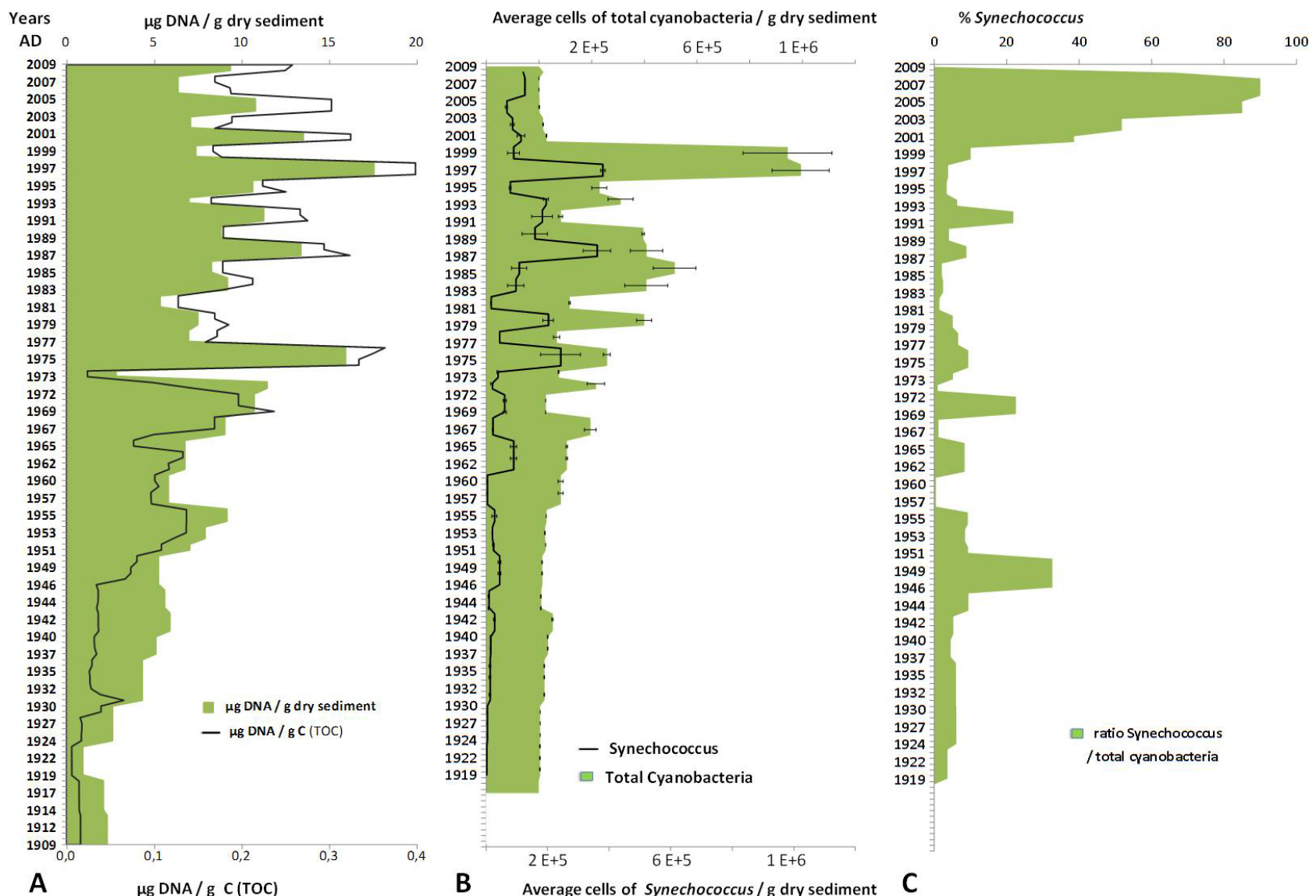

Fig. 2. Profile A shows the vertical distribution of extractable DNA quantities ( $\mu$ g per gram of dry sediment, and $\mu \mathrm{g}$ per gram of TOC). Profile B presents the abundances of total cyanobacteria (SG-rRNA-ITS) and Synechococcus (TNA-ITS), estimated by qPCR, in the sediment samples. Error bars, which are in some cases hidden by the symbols, give the standard deviations for three independent amplifications. Profile $\mathrm{C}$ presents the ratio of Synechococcus counts to total Cyanobacteria counts (qPCR data).

Table 2. Model summary for the additive mixed model fitted to the Synechococcus relative abundance (\% of total cyanobacteria as revealed by qPCR counts).

\begin{tabular}{lrrrrr}
\hline Covariate & edf & Res. df & $F$ & $P$ & Dev. (\%) \\
\hline $\begin{array}{l}\text { Summer air } \\
\text { temperature }\end{array}$ & 3.05 & 3.84 & 6.88 & 0.0009 & \\
$\begin{array}{l}\text { Annual air } \\
\text { temperature }\end{array}$ & & & & $\mathrm{NS}$ & \\
$\begin{array}{l}\text { Phosphorus } \\
\begin{array}{l}\text { Explained } \\
\text { deviance }(\%)\end{array}\end{array}$ & & & & $\mathrm{NS}$ & \\
\hline
\end{tabular}

environmental sequences from a mesotrophic Masurian lake in Poland (strains MA0607, for which the phylogenetic position was not resolved; Jasser et al., 2011), a shallow eutrophic lake in Finland (sequence AM259252 from Lake Tuusulanjarvi), together with nine sequences retrieved from Lake Bourget sediment, formed a well-defined group (here named Group I; bootstrap $91 \%$; Fig. 3). The similarities between pairs of 16SrRNA gene sequences within this group varied between 99.4 and $99.7 \%$. Group I and Group N were confirmed by two different phylogenetic analyses (maximum likelihood and neighbour joining).

It is notable that two sequences (OTUb3) fall within Group M, previously proposed as a new "Masurian clade" because it was composed of sequences from the Masurian lakes (Jasser et al., 2011).

Some rare OTUs (number of sequences lower than 3), such as OTUb14, perfectly matched reference sequences from the NCBI database. OTUb14, retrieved during two distinct periods (1991-1993 and 1972-1973) in the sediments, showed $99.5 \%$ pairwise similarity to a sequence from Lake Kanui (New Zealand; accession number: EF638720), and a $100 \%$ bootstrap associated these sequences with Group O. Of the 23 OTUs, the precise phylogenetic position of 9 rare OTUs (representing about 20 sequences in total) could not be resolved (Fig. 3), and BLAST searches failed to identify any closely related sequences in GenBank. Some of these OTUs 
Table 3. Total number of OTUs and richness estimators (SChao and SAce) obtained for each period (i.e. for each of the 8 sediment layers selected between 1951 and 2009) from 16S rRNA gene sequences ( 1100 bp alignment) presented in phylogenetic tree (Fig. 4).

\begin{tabular}{rrrrrrrrr}
\hline & $2008-2009$ & $2000-2001$ & $1991-1993$ & $1987-1988$ & $1981-1983$ & $1972-1973$ & $1956-1960$ & $1951-1952$ \\
\hline \# OTUs & BF1 & BF3 & BF10 & BF12 & BF15 & BF20 & BF24 & BF27 \\
S Chao & 8 & 7 & 10 & 7 & 7 & 10 & 5 & 8 \\
S Ace & 10 & 7 & 17 & 7 & 7 & 10 & 5 & 9 \\
\hline
\end{tabular}

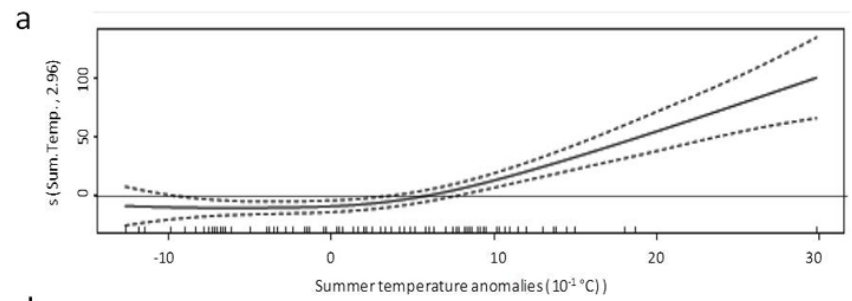

$\mathrm{b}$

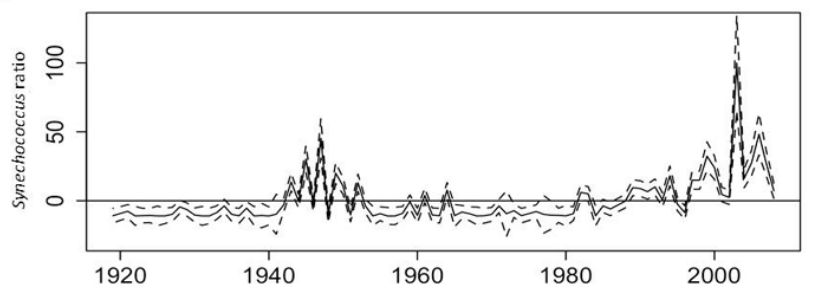

Fig. 3. GAM results: (a) Fitted smooth function for Synechococcus relative abundance (\% of total cyanobacteria as revealed by qPCR counts). The dashed lines are approximate $95 \%$ pointwise confidence intervals on the fitted function. The tick markes inside the panel on the $\mathrm{x}$-axis show the distribution of observed values for the covariates. The number in brackets on the y-axis (2.96) is the effective degree of freedom for the smooth function. (b) Contribution of summer air temperature anomalies to Synechococcus relative abundance. The dashed lines are approximate $95 \%$ pointwise confidence intervals on the contribution. Where the interval confidence includes the dashed zero line, the contribution of the covariate is not statistically significantly different from the intercept.

(i.e. OTUs 5, 6, 16, 17, 18) might be considered with caution since they occur as single sequence types in just one sediment layer and are not unambiguously associated to another reference.

\subsection{Temporal changes in the composition of Synechococcus sequences (as assessed by 16S rRNA gene region)}

The PCA plot of the Unifrac metrics $(57.4 \%$ of explained variance) showed an association between the samples from the re-oligotrophication period (i.e. 2001-2000 and 19911993) and the pre-eutrophication period (1951-1952 and 1956-1960), suggesting a similar phylogenetic composition of Synechococcus taxa for these periods. These samples were clearly opposed to those of 1987-1988 (eutrophic pe- riod) as revealed by their position on the first axis of the PCA plot (Fig. 5). On the second axis, the period 20092008 is opposed to that of 1973-1972, and the extraction of coordinates on this PCA axis enabled verification that those coordinates were, indeed, significantly correlated with phosphorus concentrations $\left(R^{2}=0.583 ; p=0.043\right)$. In contrast, no significant correlation was found with temperature. The distance matrix and $p$ values are summarised in Table S1 (Supplement).

\subsection{Synechococcus diversity based on the ITS-1 region}

Analyses of the ITS region were performed for the six OTUs defined according to the $16 \mathrm{~S}$ rRNA libraries. Only ITS sequences from related organisms can be meaningfully aligned because this spacer region is highly variable. Based on the 349 sequences affiliated with these six dominant OTUs, 21 different ITS types were found (Table 4). For each OTU, 2 to 11 ITS types were identified. The aligned ITS types showed 80-100\% similarity and each ITS type was composed of at least 2 sequences.

The most surprising finding was the diversity of ITS types found within OTU b19. Interestingly, three ITS types (19-1, 19-2, 19-3) were common in both recent and early periods (i.e. 2008-2009 and 1951-1952), and gradual modifications of other ITS types (19-4 to 19-11) from the end of the 50s to the 2000s were observed. Distinct sediment layers were characterised either by one ITS type of OTUb19 (e.g. period 1987-1988: ITS type 19-11) or by up to 4 different ITS types (e.g. period 1956-1960).

Values obtained for genetic differentiation were higher for ITS region (from 0.004 (BF3-BF1) to 0.334 (BF15-BF24)) than they were for $16 \mathrm{~S}$ rRNA (from 0.001 (BF20-BF1) to 0.089 (BF24-BF20)). The results obtained from these genetic variation estimates (both for 16s and ITS) globally tend to confirm the results obtained from UniFrac analysis. The periods of strong eutrophication (1981-1983 and 1972-1973) are clearly discriminated from other grouped periods (i.e. 20012003, 1951-1952) (Supplement, Fig. S2). The main difference with UniFrac results is the good similarity between the layer BF1 (2008-2009) and BF3 (2001-2003) for which low and nonsignificant GST values are estimated for both $16 \mathrm{~S}$ rRNA gene and ITS region. 
Table 4. ITS types identified for the 6 dominant OTUs (6 out of the 23 16S-based OTUs) obtained from the 8 clone libraries (2008-2009, 200-2001, 1991-1993, 1987-1988, 1981-1983, 1972-1973, 1956-1960, 1951-1952). The other OTUs (17 additional OTUs based on 16S analysis) are represented by 1 ITS Type. The number of clones associated to each ITS Type is specified in the table. The closest Blast hit (from NCBI BlastN) is specified for each ITS-Type.

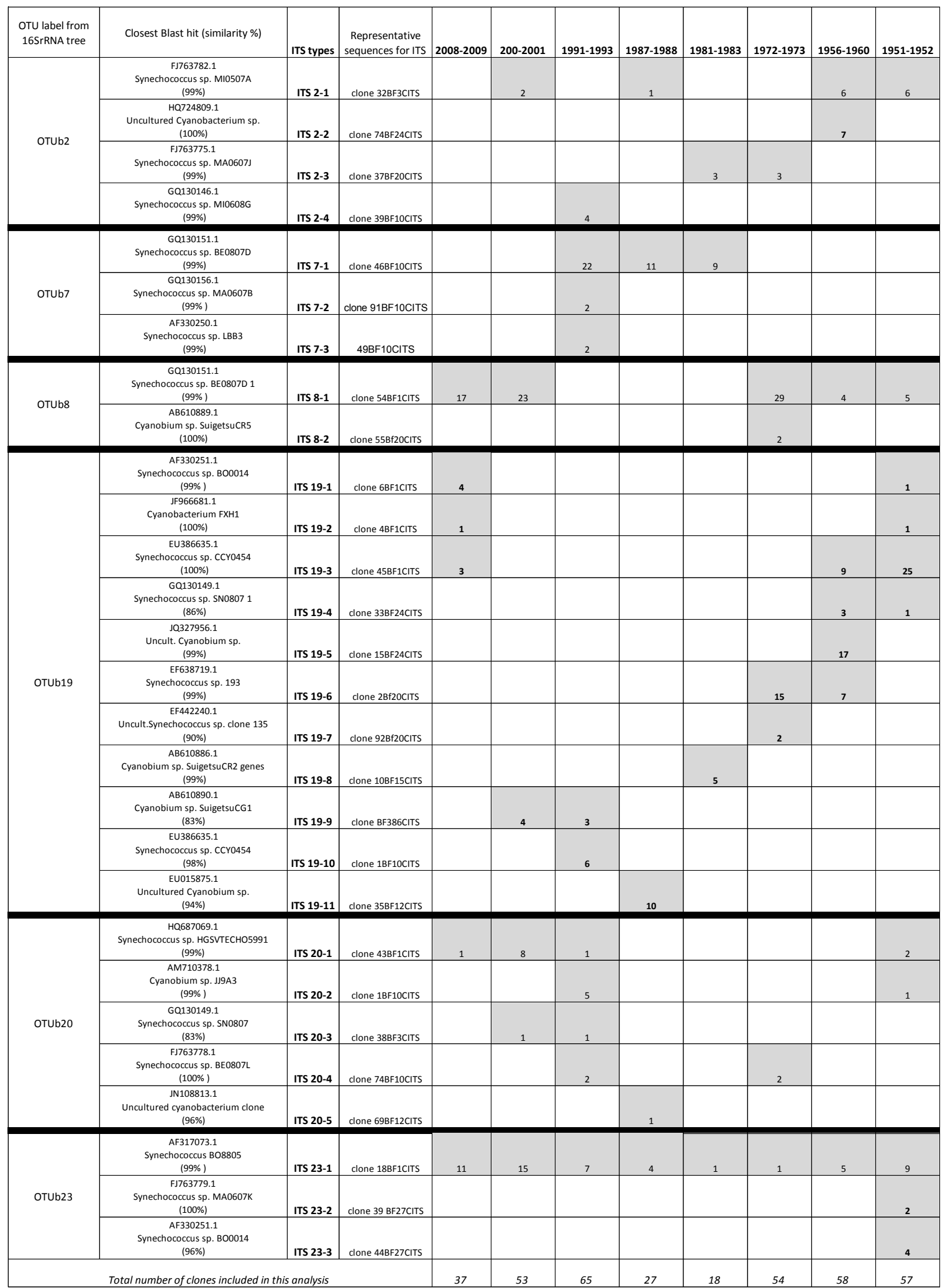




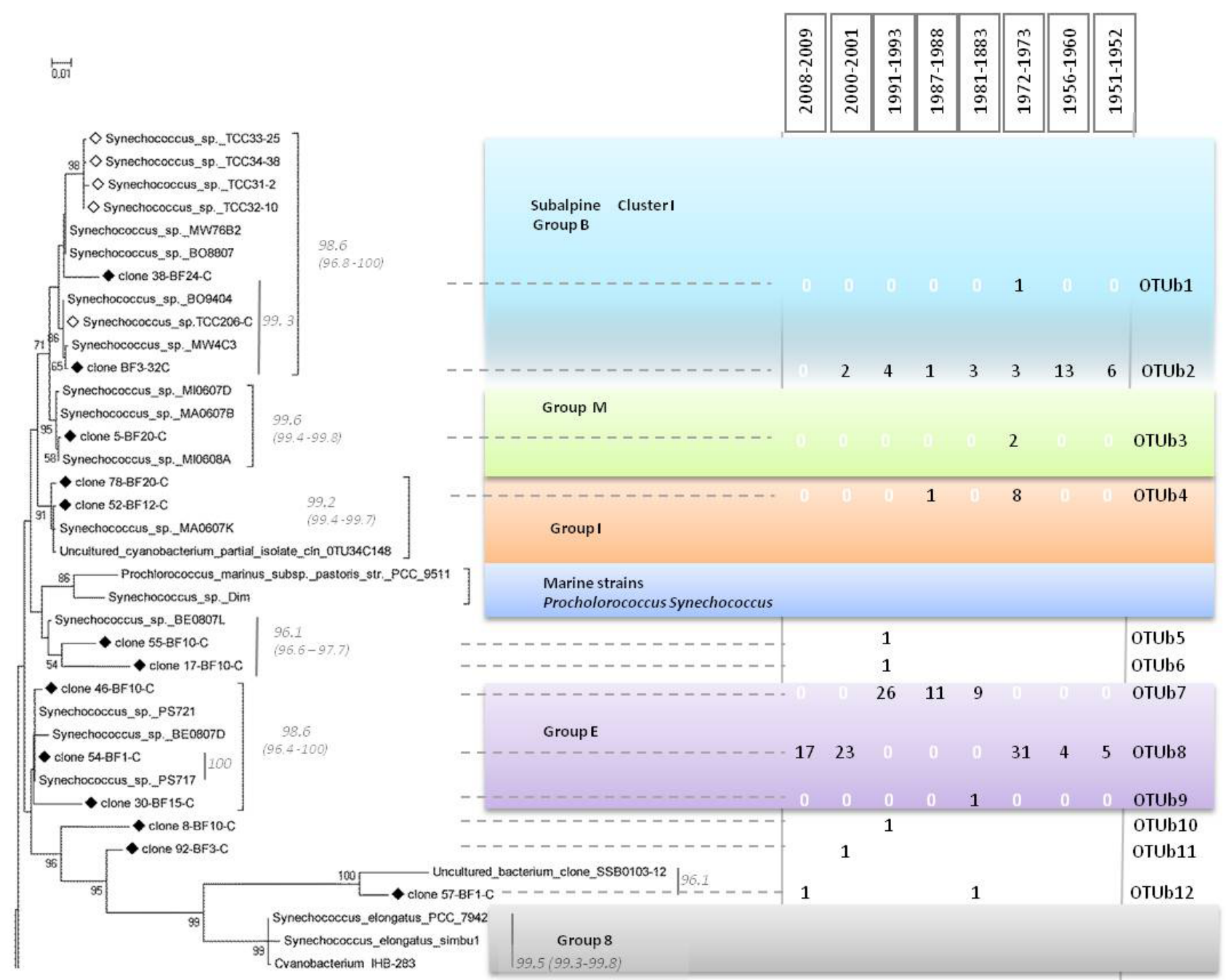

Fig. 4a. Caption on next page.

\section{Discussion}

\subsection{Coupling paleolimnology and molecular tools: strengths and limitations}

Multi-scale temporal sampling is a basic approach to adequately estimate diversity and species richness (Nolte et al., 2010, Brazelton et al., 2010). Because the characterisation of microbial community dynamics is typically performed at short or mid-term timescales (months or, at most, years), there is currently a strong need to examine the shifts in species composition from a long-term perspective, which is especially relevant when considering modification of the states of lacustrine systems. The coupling of paleolimnology with molecular tools represents a rather new and innovative method providing substantial opportunities to reconstruct the long-term, integrative dynamics of microbial diversity. There are major advantages to molecular paleoecological approaches: (i) all ancient species can potentially be studied, including those without diagnostic features retained in the sediment records; (ii) the high specificity and taxonomic resolution that are achievable using sequencing and barcode techniques (Stoof-Leichsenring et al., 2012); and (iii) the potential to analyse not only the changes in species assemblages but also to trace the population structures and histories of single species (Epp et al., 2010). Despite its potential, the genetic analysis of samples retrieved from sediment cores has been used in only a handful of studies focused on temperate and tropical lakes (Epp et al., 2010; Matisoo-Smith et al., 2007), Antarctic lacustrine systems and temperate marine systems (Coolen et al., 2004, 2006; Coolen and Overmann, 2007).

One reason for the underuse of molecular paleoecology is that it requires strong methodological constraints and caution, especially to avoid contamination by recent DNA or to provide authentication of oligonucleotide sequences from ancient DNA (Gilbert et al., 2005). Other identified limitations 


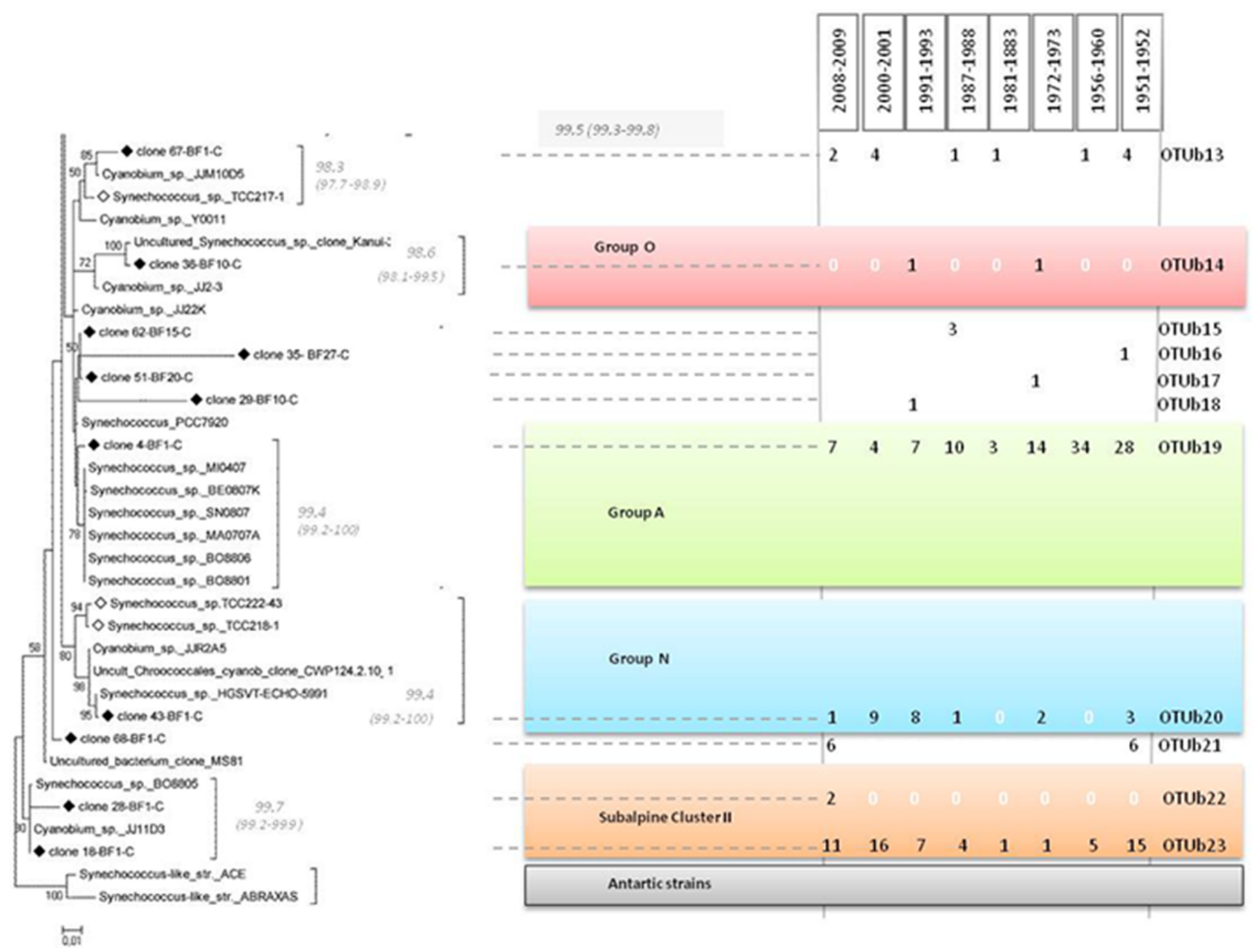

Fig. 4b. The left part present the ML phylogenetic tree obtained from partial 16S rRNA gene sequences (1100 bp alignment). Sequences from sediments (black diamond), sequences from Synechococcus strains in Thonon Culture Collection (TCC; white diamond) and sequences from GenBank database (no specific sign) were used in this phylogenetic analysis. One representative clone was selected for each of the 23 OTUs identified from the sediment samples.

A phylogenetic tree was constructed with the maximum likelihood method. ML phylogenetic trees were calculated using MEGA5 (Tamura et al., 2011). The ML analyses were carried out using the optimum model of sequence evolution selected according to the Akaike information criterion (as a result the GTR $+\mathrm{G}+\mathrm{I}$ model of nucleotide substitution was used). The tree topology was confirmed by 1000 bootstrap replications. Number at nodes indicate the percentage of bootstrap frequency, bootstrap values of $<50 \%$ are not shown. The scale bar represents the number of substitution per nucleotide position.

The Abraxas and Ace, Synechococcus isolates from Vestfold Hill Lakes, eastern Antarctica (Vincent et al., 2000), are sister to the marine and freshwater lineages (Sanchez-Baracaldo et al., 2008), therefore these strains were used when rooting. Group/clade composition was confirmed by the neighbor joining analysis which was also done using the correction of Jukes and Cantor (1969) with 1000 bootstrap.

On the right part, the number of clones associated to each OTU in the different layers of the dated sediment is reported. Some of the OTUs (i.e. OTUs 5, 6, 16, 17, 18) might be considered with caution since they occur as single sequence types in just one sediment layer and are not unambiguously associated to another reference.

Subalpine cluster I \& subalpine cluster II were described by Ernst et al. (2003) and contain Synechococcus sequences originating notably from several deep subalpine lakes, such as lakes Constance, Zurich, Maggiore, and Leman (central Europe). Group M was initially described by Jasser et al (2011) from Synechococcus sequences originating from Masurian lakes (Poland).

Group I is a cosmopolitan group containing Synechococcus sequences that originate from various lakes (Masurian Lakes (Poland), Lake Bourget (France), shallow lakes in Finland, etc.).

Group E is a cosmopolitan group initially described as being specific to Japanese lakes (Robertson et al., 2001).

Group A is a cosmopolitan group that gathers both pigment types (i.e. PE or PC-rich) as reported by Crosbie et al (2003).

Group O, newly named here, gathers Synechococcus sequences from Lake Kanui (New Zealand) and Lake Bourget.

Group N is a cosmopolitan group, newly named here, it gathers Synechococcus sequences obtained from taxa isolated from various freshwater systems (i.e. lakes Annecy and Bourget (France), Rimov reservoir (Czech Republic), and Lake 124 (UK)). 


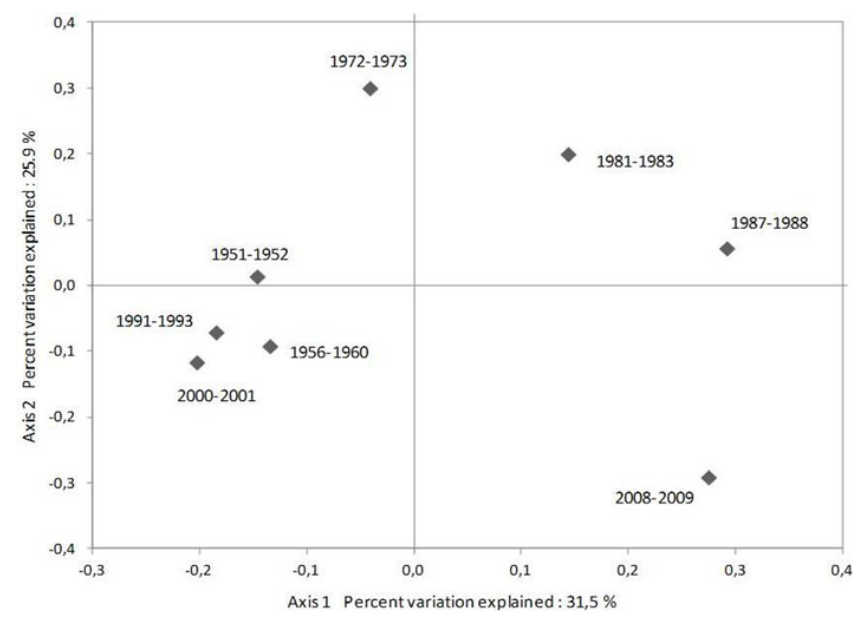

Fig. 5. PCA plot obtained from UNIFRAC analysis comparing the Synechococcus phylogenetic composition (based on the 16S OTUs) of the 8 clone libraries (BF1: 2008-2009, BF3: 2000-2001, BF10: 1991-1993, BF12: 1987-1988, BF15: 1981-1983, BF20: 19721973, BF24: 1956-1960, BF27: 1951-1952).

are due to taphonomic processes, including the degradation of ancient DNA into short fragments within the first several thousand years after deposition (D'Abbadie et al. 2007; Gilbert et al., 2005) and the variable conditions of organic matter preservation from one ecosystem to another (Boere et al., 2011). The extent to which DNA is preserved and the factors/conditions that control the preservation of DNA in lacustrine sediments remain partly unknown, and these issues must be addressed when ancient DNA techniques are applied. Anoxic conditions, absence of bioturbation, and low temperature are among the most crucial factors promoting DNA preservation (Boere et al., 2011). Prior to our study, we conducted a validation study to assess the possible PCR inhibition due to co-extracted material and the quality and integrity of the archived DNA. PCR amplification of several sizes of fragments were tested, the obtained amplicons were submitted to sequencing in order to compare the picture of taxonomic compositions provided by sequencing short ( $\sim 150 \mathrm{bp}$ ) and long (up to $1500 \mathrm{bp}$ ) amplicons originating from the same sediment layers. The results showed that whatever the length of sequenced amplicons was, we obtained quite similar composition for cyanobacterial assemblages (in terms of proportion of putative genera), and more particularly the amplification of long DNA fragments did not lead to any lost of richness (number of cyanobacterial genera detected) in comparison to short fragments (Supplement, Table S2). The high level of DNA preservation was thus confirmed in these sediment layers and notably for Synechococcus DNA that dominated all the libraries of clones. To confirm the preservation of organic material, we also analysed pigments from the same sediment layers, focusing particularly on zeaxanthin, which is mainly present in cyanobacterial cells (BF2 to BF34; Supplement, Fig. S3).
In Lake Bourget, we could retrieve well-preserved long DNA fragments (up to $1500 \mathrm{bp}$ ), which is rare for environmental DNA studies. The principal reason for such a high quality of archived DNA in the present study is that we focused on a relatively recent time period (the past century) and on well-preserved organic material (DNA). Second, the concave morphology of deep subalpine lakes favours a predominantly direct sedimentation process without sediment remobilisation/resuspension (Alric and Perga, 2011) that restricts the interval for which organic matter and, thus, DNA is exposed to degradative agents within the water column. Moreover, the cold deep-water layers and undisturbed laminated sediments may promote the preservation of DNA while buried in the sediments. In a hard-water lake such as Lake Bourget, the calcite precipitation process that occurs each year during spring and summer (Groleau et al., 1999) allows a rapid burying of organic matter (organic particulate matter is associated with the authigenic calcite flux), causing a rapid sedimentation of PC along the water column. PC peaks occur simultaneously with high calcite concentrations in Lake Bourget and they might play a role in calcite precipitation as described in Lake Lucerne where bacteria-shaped particles covered with precipitated calcite were observed (Dittrich et al., 2004). This calcite cover around PC cells that can persist while buried in the sediment might be another reason for the exceptionally good preservation of their DNA in our study lake. Finally, these deep hard-water subalpine lakes are certainly good model systems in which to perform molecular paleolimnological studies.

\subsection{Synechococcus temporal dynamics}

Within lacustrine picophytoplaktonic assemblages, PC are generally numerous in comparison to their pico-eukaryotic counterparts (e.g. Personnic et al., 2009). PC are known to be favoured by the stability of the vertical structure of lakes and by high hydrological retention times. Therefore, temperate large deep lakes generally constitute favourable environments for the success of PC (Stockner et al., 2000). The seasonal and annual dynamics of PC have been described in several large deep lakes (including Lake Bourget), showing either a typical bimodal pattern of their abundance maxima, with a spring or early summer peak and a second peak during autumn (Berdjeb et al., 2011, see Callieri, 2008 for a review), or the maintenance of high and fairly stable densities from early spring to late autumn in oligotrophic deep lakes (Personnic et al., 2009). The dominance of PC (particularly Synechococcus spp.) in nutrient-poor waters, even during severe phosphorus depletion, is mostly explained by their high affinity for orthophosphate (Moutin et al., 2002) and their high cell-specific $\mathrm{P}$ uptake rates in comparison to other algae and bacteria (Pitt et al., 2010, Vadstein, 2000). An alternative explanation for the relative success of PC at low P concentrations is the ability of their cells to utilise organic sources of phosphate, and/or to substitute sulphate $\left(\mathrm{SO}_{4}^{2-}\right)$ for $\mathrm{PO}_{4}^{3-}$ 
in lipids (Van Mooy et al., 2006; Callieri and Stockner, 2000; Jansson et al., 1988). Based on this knowledge and considering the global context of re-oligotrophication resulting from the intensive restoration efforts for many temperate lakes (e.g. lakes Constance, Maggiore, Bourget and Geneva), several authors have hypothesised the increased importance of PC within planktonic food webs under re-oligotrophicated conditions. Indeed, in Lake Maggiore (Italy), dominance by autotrophic picoplankton, mainly Synechococcus, developed following the oligotrophication of the lake (Ruggiu et al., 1998; Callieri and Piscia, 2002).

The Synechococcus dynamics we reconstructed here (by qPCR, from sedimentary DNA) is in good agreement with the observations reported from Lake Constance by Kamjunke et al. (2009) who showed that autotrophic picoplankton had low biomass at low and high phosphorus concentrations and maximum biomass at moderate $\mathrm{P}$ concentrations. However, because we cannot assume that the DNA was preserved with exactly the same efficiency in the different layers, the absolute counts obtained by qPCR along the sediment core should be considered with caution. For this reason, we considered only the relative counts of Synechococcus (i.e. quantification of Synechococcus in terms of their ratio to total cyanobacteria) in additive models that were used to disentangle the respective effects of phosphorus concentration and temperature (air temperature anomalies) on the dynamics of Synechococcus (in terms of their contribution to total cyanobacteria). The highest proportions of Synechococcus (within cyanobacterial assemblages) were observed over the last decade, concomitant with the recent warming, thus suggesting that climatic parameters might significantly affect Synechococcus community dynamics. Indeed, the GAM results showed a significant effect of summer temperature (June to September) on the proportion of Synechococcus, while the trophic status was not found to have significant influence. Several authors have previously reported that PC growth is, indeed, stimulated by increased summer temperatures (as observed, for instance, by Collos et al., 2009 in the Thau lagoon), but long-term data showing such a significant impact is rare. Our results suggest that positive anomalies of summer temperature could have a significant impact on the structures of cyanobacteria populations (picocyanobacteria vs. larger cyanobacteria), at least under oligo-mesotrophic conditions. Large-scale climate changes are known to affect the deep subalpine lakes, inducing overall warming of the water and causing changes in the timing of stratification (Dokulil et al., 2006; Anneville et al., 2007). However, our understanding of re-oligotrophication and warming effects on pelagic food webs is almost entirely restricted to the classical food chain (i.e. microphytoplankton, zooplankton and fish), whereas studies documenting the response of the microbial food web are rare (Kamjunke et al., 2009). Data from long-term monitoring of microbial planktonic communities are generally missing, but the genetic paleolimnological approach offers a good alternative, which enables investigation of qualitative and quantitative changes in microbial communities and, particularly, in PC, as we illustrated in this study.

\subsection{Synechococcus long-term diversity}

Our data provided new insights into the long-term molecular diversity of Synechococcus from Lake Bourget, revealing 23 OTUs from the partial 16S rRNA gene libraries. A molecular approach by DNA-based analyses is essential not only for paleolimnological but also ecological studies on Synechococcus because their cells lack sufficient discernible morphological features to provide robust taxonomic identification as distinct species. Phylogenetic analyses of 16S rRNA gene sequences were essential to reveal that Cyanobium, Marine clusters A and B and Prochlorococcus, together with freshwater Synechococcus, form a coherent phylogenetic group, representing a single picophytoplankton clade distinct from the rest of the cyanobacteria (Urbach et al., 1998; Crosbie et al., 2003; Ernst et al., 2003). Recently, numerous studies have pursued investigations on the phylogenetic diversity of natural Synechococcus populations (Becker et al., 2007; Ivanikova et al., 2007; Jasser et al., 2011; Wu et al., 2010). Understanding the genetic structure of these picocyanobacteria in situ is, therefore, an important task for elucidating the biological and physical factors controlling the presence or absence of particular lineages (Zwirglmaier et al., 2008) and for addressing the issues important to their microbial biogeography (endemic vs. cosmopolitan microbial populations) (e.g. Martiny et al., 2006). The genus Synechococcus is, indeed, considered to be one of the most widely distributed cyanobacteria; however, considering the variety of its genotypes, some authors have recently suggested a spatial partitioning of individual PC lineages at the global scale in marine systems (i.e. different signature Prochlorococcus and Synechococcus lineages observed in the four major ocean domains or biomes; Zwirglmaier et al., 2008). Similarly, the existence of novel freshwater clades or groups described as being specific to a certain geographical area has been suggested. For example, Jasser et al. (2011) suggested the existence of endemic species in the Masurian lakes (sequences affiliated to Group M), and consequently, the possibility of geographic boundaries for PC. However, our data showed that Group M, described as specific to the Great Masurian Lakes system (GMLS), is a cosmopolitan group. Indeed, we identified several sequences from Lake Bourget that clustered together with isolates from the GMLS. Similarly, Group E (mainly phycoerythrin-rich cells as reported by Robertson et al., 2001) was previously described as being specific to a certain geographical region (lakes in Japan). However, our results showed that this lineage was well represented in the PC assemblage of Lake Bourget consistently during the past century (OTUs b7 and 8 (Fig. 4) are affiliated with this group). These data demonstrate that greater care should be taken before inferring conclusions about the geographic restriction of novel PC clades, as recently noted 
by Felföldi et al. (2011). To our knowledge, the Subalpine clusters I and II (four OTUs from our dataset, Fig. 4) remain specific for a geographical region. The rest of the dominant OTUs (based on 16S rRNA phylogeny) identified in this study should be considered cosmopolitan taxa because they clustered with strains isolated from various geographic places. Moreover, the dominant OTUs were generally retrieved from all 8 sediment layers for which the phylogenetic analyses were performed. We note, however, one exception within cosmopolitan group E, in which two distinct OTUs (97\% similarity level for the 16S rRNA gene) were identified. The first, OTUb7, is clearly associated with the "eutrophic conditions" period and was close to the genotype of BO 8807 (isolated from Lake Constance). It is interesting to note that $\mathrm{BO} 8807$ was identified as a strain requiring higher phosphate concentrations for maximum growth rates compared with a strain from the same phylogenetic cluster that dominates the pelagic summer population (Becker et al., 2002). The second OTU (OTUb8) from Group E was associated with transitional oligo-mesotrophic periods, suggesting a shift in the genetic composition of this cosmopoli$\tan$ group $\mathrm{E}$ in response to the changes in environmental (nutrient resources) conditions.

Using UniFrac analysis, we showed that phosphorus concentration (lake trophic state) was related to the changes in the global phylogenetic composition (16S OTUs) of the Synechococcus assemblages through time. Moreover, the study of the ITS region revealed a higher level of diversity that was not detectable due to the limits of the OTU definition (Table 4) that also suggested a link between the lake's trophic state and the genetic composition of the Synechococcus population. Up to eleven ITS types were detected for OTUb19 that is a part of the cosmopolitan Group A (cluster Cyanobium gracile). Interestingly, the distribution pattern of these 11 ITS types could be linked to the trophic status of the lake because a gradual change in genetic composition detectable by ITS analysis was observed in response to the eutrophication and re-oligotrophication processes. These observations confirmed the hypothesis that the dominance of Synechococcus spp. within picoplanktonic assemblages was achieved by the evolutionary adaptation and co-existence of numerous genotypes, most likely generating physiologically highly diverse populations.

Overall, our results showed that environmental changes impacted Synechococcus community structure, translating into changes in genotype composition (based on both $16 \mathrm{~S}$ rRNA and ITS). Indeed, beyond the changes in Synechococcus proportion that are correlated to temperature, our results suggest a genetic differentiation within Synechococcus assemblage that might be linked to trophic status (similar genotypes at a certain trophic state) and possibly to other environmental factors which have not taken into consideration. However, our results do not allow the identification of ecotypes. SSU rDNA and ITS sequences represent a useful resource for determining the phylogenetic relationships of se- quences within closely related strains derived from natural environmental samples (a large amount of sequence data is now available in GenBank), but conserved genetic markers such as SSU rRNA may not provide the best molecular resolution to identify ecotypes adapted to distinct ecological niches. For this specific purpose, other marker genes have to be developed and validated. Recently, multi-locus sequence analysis was employed by Mazard et al. (2011) to provide the taxonomical resolution of marine Synechococcus isolates showing that the recent availability of full genome sequences for several Synechococcus strains (Dufresne et al. 2003; Rocap et al. 2003; Palenik et al. 2003, 2006) offers the opportunity to identify new relevant gene makers for ecological studies on the mechanism of niche adaptation (Jonhson et al., 2006; Mazard et al., 2012). The combination of such genetic knowledge with a paleolimnological approach within an ecological framework should facilitate our understanding of the factors controlling the distribution and diversity of freshwater PC biodiversity and, more globally, of lacustrine microbial organisms.

\section{Conclusions}

Molecular tools are able to serve paleolimnological issues, for instance, to reconstruct the dynamics and diversity of freshwaters microbial communities for which we have no long-term monitoring data. These results regarding longterm changes in composition and structure of microbial communities in freshwater systems should contribute to a description of genotypes' temporal and spatial distributions with major implications for the reconstruction of biodiversity histories. The large-scale (multi-lakes) application of molecular-paleolimnological studies may provide unprecedented data that may allow reconstruction of the historical biogeographic distributions of taxa as well as their responses to environmental parameter changes. A multi-lakes study, performed at the regional scale (i.e. among subalpine deep lakes) could, for instance, be of great interest to confirm our hypothesis about the effect of summer temperature on picocyanobacteria dynamics. The next challenging step might also be the study of changes in biodiversity in more complex biological assemblages, e.g. microbial eukaryotes (i.e. protists). However, because the diagenetic processes that occur as sediment ages may affect DNA signatures, and the resistance to degradation of DNA might be group-specific (depending on the characteristics of cells: production of cysts, presence of specific cell walls such as in chlorophytes, etc.), additional work regarding the efficiency of preservation of the DNA signal through time for various phylogenetic groups is needed before applying this approach to complex eukaryote assemblages. 


\section{Appendix A}

\section{Age models of reference cores and sample dating}

Cores were sampled using a UWITEC gravity corer. They were split lengthwise, photographed and described. On every core (reference and working core), descriptions included well-documented lithological markers: (i) dark layers related to historical floods events; (ii) gravity-reworked deposits; and (iii) outstanding white diatoms layers. Where they were present (from the 1940s), varves were counted directly on cores. This was possible as each doublet was relatively thick (>2 mm). The working core LDB 09P2 was correlated to the reference one (LDB04P1), using both lithological markers and lamina counting hence allowing an annual temporal resolution at least on the laminated part of cores. For age models, ${ }^{210} \mathrm{~Pb},{ }^{226} \mathrm{Ra},{ }^{137} \mathrm{Cs}$ and ${ }^{241} \mathrm{Am}$ activities were measured by gamma spectrometry on the reference core LDB04P1 at the Modane underground laboratory (LSM) environmental radioactivity facility (Reyss et al., 1995). Measurements were made on 1-3 g of dried sediment, using high-efficiency, very low-background, well-type germanium detectors (Reyss et al., 1995). Six standards were used to calibrate the gamma detectors (Cazala et al., 2003). Generally, 24-48 h of counting time were required to reach a statistical error below $10 \%$ for excess ${ }^{210} \mathrm{~Pb}$ in the deepest samples and for the 1963 peaks of ${ }^{137} \mathrm{Cs}$ and ${ }^{241} \mathrm{Am}$. The excess ${ }^{210} \mathrm{~Pb}$ (i.e. formed in the atmosphere by the decay of ${ }^{222} \mathrm{Rn}$ ) was calculated as the difference between the total ${ }^{210} \mathrm{~Pb}$ and ${ }^{226} \mathrm{Ra}$ (supported ${ }^{210} \mathrm{~Pb}$ ) activities. This calculation is based on the assumption that the intermediate daughter product, ${ }^{222} \mathrm{Rn}$, is in equilibrium with ${ }^{214} \mathrm{~Pb}$ (i.e. ${ }^{226} \mathrm{Ra}$, Arnaud et al 2006). The CFCS model (Constant Flux, Constant Sedimentation, Golberg 1963, Krishnaswami et al., 1971) was chosen for this study because sediment rate is dominated by constant sedimentation for recent sediments and because atmospheric flux of radionuclide ${ }^{210} \mathrm{~Pb}$ is constant, as shown by the linear radionuclides decrease (Lake Bourget, $\mathrm{R}^{2}=0.937$ ). Whatever the model or procedure used, ${ }^{210} \mathrm{~Pb}$-based chronologies must always be confirmed by independent methods (Smith, 2001). Generally, ${ }^{210} \mathrm{~Pb}$ dates are confirmed using ${ }^{137} \mathrm{Cs}$ profiles, when the ${ }^{137} \mathrm{Cs}$ profiles are sufficiently intact (Appleby and Oldfieldz, 1983).

The ${ }^{210} \mathrm{~Pb}_{\text {exc }}$ profiles in the reference core showed a regular and exponential decay in relation to depth. CFCS age modeling indicated an average sedimentation rate of $4.0 \mathrm{~mm} \mathrm{yr}^{-1}$ for Lake Bourget.

The ${ }^{137}$ Cs activity vs. depth profile showed a small peak at $8.3 \mathrm{~cm}$ depth, without any increase in ${ }^{241} \mathrm{Am}$ activity, corresponding to the fallout from Chernobyl accident in 1986. This chronological marker implied an average sedimentation rate of $4.4 \mathrm{~mm} \mathrm{yr}^{-1}$ for Lake Bourget between 1986 and 2005. The well-resolved peak of ${ }^{137} \mathrm{Cs}$, visible at $17.5 \mathrm{~cm}$, coinciding with a peak of ${ }^{241} \mathrm{Am}$ confirmed that sediment at these depths were deposited at the period of max- imum artificial radionuclide fallout due to nuclear weapon tests in 1963. Age-depth relationships corresponded to an average sediment rate of $4.2 \mathrm{~mm} \mathrm{yr}^{-1}$ between 1963 and 2005. The good agreement between average sedimentation rates deduced from ${ }^{210} \mathrm{~Pb}_{\text {exc }},{ }^{137} \mathrm{Cs}$ and ${ }^{241} \mathrm{Am}$ profiles allowed the extrapolation of the regular sedimentation rate of $4.2 \mathrm{~mm} \mathrm{yr}^{-1}$ giving $183 \mathrm{yr}$ of sedimentation.

\section{Appendix B}

\section{Diatom-inferred TP annual concentrations (DI-TP, Berthon et al., 2013)}

Annual mean total phosphorous concentrations ([TP]) were reconstructed from a diatom-based inference model based on 86 surface sediment samples collected in lakes around the Alps along a trophic gradient (Wunsam and Schmidt, 1995). The calibration dataset covered a large trophic gradient, with mean annual TP ranging from $2-266 \mu \mathrm{gPL}^{-1}$. Several models were tested: weighted averaging with classical deshrinking $\mathrm{WA}_{\text {cla }}$ regression, weighted averaging with inverse deshrinking $\mathrm{WA}_{\text {inv }}$ regression (Ter Braak and Van Dame, 1989), weighted averaging partial least squares regression (WAPLS - Ter Braak and Juggins, 1993), Modern Analogue Technique (MAT) with squared chord distance (Overpeck et al., 1985); and their relative performances were estimated using the $r^{2}$ and the root mean square error of prediction (RMSEP) calculated after a cross validation method (bootstrapping, 500 permutations) on the calibration dataset.

The selected model was then applied to a diatom biostratigraphy of Lake Bourget from Millet et al. (2010). DI-TP reconstructions were performed using program $\mathrm{C} 2$ (version 1.7.2, Juggins, 2007). [TP] in Lake Bourget water column had been measured sporadically in the 1970s and then monitored from 2004. These monitoring data could hence be used to confirm the models relevancy (Database SOERE-INRA of Thonon-les-Bains - France).

Compared to WA and WAPLS models, MAT models had the lowest performance. There were no relevant differences between WA and WAPLS models performances. Statistical results for DI-TP showed a relatively good predictive ability of the WA model with classical deshrinking $\left(r_{\text {jackknife }}^{2}=\right.$ 0.604 , RMSEP $=0.34 \log$ unit). Of all the samples from Lake Bourget, $91 \%$ of the fossil assemblage was comparative to the training set of the DI-TP. The bootstrapped average bias was low $(0.92 \%)$

Generally, DI-TP changes were consistent with expected dynamics. Values and timing of DI-TP maxima matched measured TP (Fig. B1), and DI-TP for current time periods were in close agreement with the monitored chemical data. 


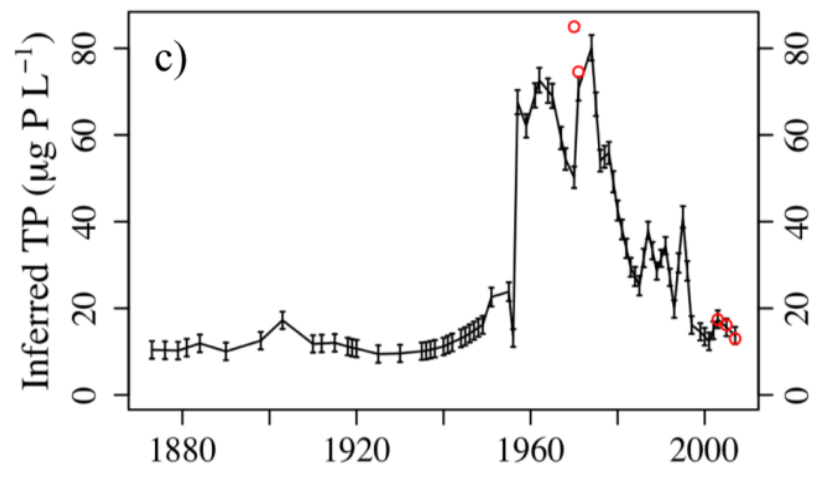

Fig. B1. Temporal changes of (TP) as reconstructed from the diatom-transfer functions (Inferred TP (continuous line, left axis), and measured water (TP) (red open circles, right axis)) in Lake Bourget.

\section{Supplementary material related to this article is

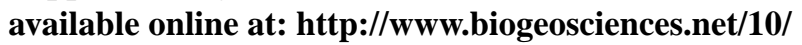 3817/2013/bg-10-3817-2013-supplement.pdf.}

Acknowledgements. For financial support we thank the French National Research Agency (France) who supported the program "Iper Retro" (ANR VULNS-005) and the INEE (CNRS France) who supported the PEPS program "ADN messager".

For the substantial work dealing with diatoms identification and for providing the results of the diatom transfer function, we thank Vincent Berthon (CARRTEL INRA). For her assistance in molecular biology analyses, and in managing Synechococcus strains cultures, we wish to especially thank Cécile Chardon (CARRTEL INRA). We also thank J. Poulenard (EDYTEM University of Savoie) who performed the TOC measurements by Pyrolysis Rockeval method, and S. Jacquet (CARRTEL INRA) who isolated the Synechococcus strains in 2005 from 3 subalpine lakes (Bourget Annecy Léman) in order to enrich the Thonon Culture Collection with freshwater picocyanobacteria. For their technical help in the field, we thank EDYTEM (CNRS) staff who participated in the sediment coring on Lake Bourget. Finally, we want to thank I. Gregory Eaves (Mac Gill University, CA) for her very useful comments

The correction of English language was performed using "English Language Editing" Elsevier service.

Edited by: K. Suzuki

\section{References}

Agawin, N. R. S., Duarte, C. M., and Agustí, S.: Nutrient and temperature control of the contribution of picoplankton to phytoplankton biomass and production, Limnol. Oceanogr., 45, 591600,2000

Alric, B.: Influence des perturbations locales sur la vulnérabilité et la réponse des réseaux trophiques pélagiques lacustres face au changement climatique : une approche paléo-écologique basée sur les cladocères, $\mathrm{PhD}$ Thesis, University of Grenoble, Chambéry, France, 180 pp., 2012.

Alric, B. and Perga, M. E.: Effects of production, sedimentation and taphonomic processes on the composition and size structure of sedimenting cladoceran remains in a large deep subalpine lake: paleo-ecological implications, Hydrobiologia, 676, 1, 101-116, 2011.

Altschul, S. F., Gish, W., Miller, W., Myers, E. W., and Lipman, D. J.: Basic local alignment search tool, J. Mol. Biol., 215, 403-410, 1990.

Anneville, O., Molinero, J. C., Souissi, S., Balvay, G. and Gerdeaux, D.: Long-term changes in the copepod community of Lake Geneva, J. Plankton Res., 29(Supplement 1), 149-159, 2006.

Auer, I., Böhm, R., Jurkovic, A., Lipa, W., Orlik, A., Potzmann, R., Schöner, W., Ungersböck, M., Matulla, C., Briffa, K., Jones, P., Efthymiadis, D., Brunetti, M., Nanni, T., Maugeri, M., Mercalli, L., Mestre, O., Moisselin, J.-M., Begert, M., MüllerWestermeier, G., Kveton, V., Bochnicek, O., Stastny, P., Lapin, M., Szalai, S., Szentimrey, T., Cegnar, T., Dolinar, M., GajicCapka, M., Zaninovic, K., Majstorovic, Z., and Nieplova, E. : HISTALP - historical instrumental climatological surface time series of the Greater Alpine Region, Inter. J. Climatol., 46, 1746, 2007.

Battarbee, R. V., Jones, V. J., Flower, R. J. Cameron, N. G., Bennion, H., Carvalho, L., and Juggins, S.: Diatoms, in: Tracking Environmental Change Using Lake Sediments-Volume 3: Terrestrial, Algal, and Siliceous Indicators, edited by: Smol, J. P., Birks, H. J. B., and Last, W. M., Kluwer Academic Publishers, Dordrecht, Boston, London, 155-202, 2001.

Becker, S., Fahrbach, M., Böger, P., and Ernst, A.: Quantitative Tracing, by Taq Nuclease Assays, of a Synechococcus ecotype in a highly diversified natural population, Appl. Environ. Microb. 68, 4486-4494, 2002.

Becker, S., Richi, P., and Ernst, A.: Seasonal and habitat-related distribution pattern of Synechococcus genotypes in Lake Constance, FEMS Microbiol. Ecol., 62, 64-77, 2007.

Becker, S., Sanchez-Baracaldo, P., Singh, A. K., and Hayes, P. K.: Spatio temporal niche partitioning of closely related picocyanobacteria clades and phycocyanin pigment types in Lake Constance (Germany), FEMS Microbiol. Ecolol., 80, 488-500, 2012.

Berdjeb, L., Pollet, T., Domaizon, I., and Jacquet, S.: Effect of grazers and viruses on bacterial community structure and production in two contrasting trophic lakes, BMC Microbiol., 11, 88, 2011.

Berthon, V., Marchetto, A., Rimet, F., Dormia, E., Jenny, J. P., Pignol, C., and Perga, M. E.: Trophic history of French sub-alpine lakes over the last $\sim 150$ years: phosphorus reconstruction and assessment of taphonomic biases, J. Limnol., in press, 2013.

Boere, A. C., Rijpstra, W. I. C., De Lange, G. I., Damste, J. S. S., and Coolen, M. J. L.: Preservation potential of ancient plankton DNA in Pleistocene marine sediments, Geobiology, 9, 377-393, 2011.

Brazelton, W. J., Ludwig, K. a, Sogin, M. L., Andreishcheva, E. N., Kelley, D. S., Shen, C.-C., Edwards, R. L., and Baross, J. A.: Archaea and bacteria with surprising microdiversity show shifts in dominance over 1000-year time scales in hydrothermal chimneys., P. Natl. Acad. Sci. USA, 107, 1612-1617, 2010. 
Bustin, S. A., Benes, V., Garson, J. A., Heliemans, J., Huggett, J., Kubista, M., Mueller, R., Nolan, T., Pfaffl, M. W., Shippley, G. L., Vandesompele, J., and Wittwer, C. T.: The MIQE guidelines: minimum information for publication of quantitative real-time PCR experiments, Clin. Chem., 55, 611-622, 2009.

Callieri, C.: Picophytoplankton in freshwater ecosystems: the importance of small-sized phototrophs, Freshwater Rev., 1-28, 2008.

Callieri, C. and Pinolini, M. L.: Picoplankton in Lake Maggiore, Italy, Int. Rev. Ges. Hydrobiol., 80, 491-501, 1995

Callieri, C. and Piscia, R.: Photosynthetic efficiency and seasonality of autotrophic picoplankton in Lago Maggiore after its recovery, Freshwater Biol., 47, 941-956, 2002.

Callieri, C. and Stockner, J. G.: Picocyanobacteria success in oligotrophic lakes: fact or fiction?, J. Limnol., 59, 72-76, 2000.

Callieri, C. and Stockner, J. G.: Freshwater autotrophic picoplankton: a review, J. Limnol., 61, 1-14, 2002.

Caron, D. A., Pick, F. R., and Lean, R. A.: Chrococcoïd cyanobacteria in Lake Ontario: seasonal and vertical distribution during 1982, J. Phycol., 21, 171-175, 1985.

Cazala, C., Reyss, J. L., Decossas, J. L., and Royer, A.: Improvement in the determination of $238 \mathrm{U}, 228-234 \mathrm{Th}, 226-228 \mathrm{Ra}$, $210 \mathrm{~Pb}$, and $7 \mathrm{Be}$ by gamma spectrometry on evaporated fresh water samples, Environ. Sci. Technol., 37, 4990-4993, 2003.

Chao, A.: Nonparametric estimation of the number of classes in a population, Scand. J. Stat., 11, 265-270, 1984.

Chao, A. and Lee, S. M.: Estimating the number of classes via sample coverage, J. Am. Stat. Assoc., 87, 210-217, 1992.

Collos, Y., Bec, B., Jauzein, C., Abadie, E., Laugier, T., Lautier, J., Pastoureaud, A., Souchu, P., and Vaquer, A.: Oligotrophication and emergence of picocyanobacteria and a toxic dinoflagellate in Thau lagoon, southern, J. Sea. Res., 61, 68-75, 2009.

Coolen, M. J. L. and Overmann, J.: 217000 -year-old DNA sequences of green sulfur bacteria in Mediterranean sapropels and their implications for the reconstruction of the paleoenvironment, Environ. Microbiol., 9, 238-249, 2007.

Coolen, M.J. L. and Gibson, J. A. E.: Ancient DNA in lake sediment records, PAGES news, 17, 104-106, 2009.

Coolen, M. J. L., Muyzer, G., Rijpstra, W. I. C., Schouten, S., Volkman, J. K., and Damste, J. S. S.: Combined DNA and lipid analyses of sediments reveal changes in Holocene haptophyte and diatom populations in an Antarctic lake, Earth Planet. Sc. Lett., 223, 225-239, 2004.

Coolen, M. J. L., Muyzer, G., Schouten, S., Volkman, J. K., and Sinninghe Damsté, J. S.: Sulfur and methane cycling during the Holocene in Ace Lake (Antarctica) revealed by lipid and DNA stratigraphy, in: Past and Present Marine Water Column Anoxia, NATO Science Series: IV-Earth and Environmental Sciences, edited by: Neretin, L. N., Springer, Dordrecht, 41-65, 2006.

Coolen, M. J. L., Talbot, H. M., Abbas, B. A., Ward, C., Schouten, S., Volkman, J. K., and Sinninghe Damsté, J. S. Sources for sedimentary bacteriohopanepolyols as revealed by $16 \mathrm{~S}$ rDNA stratigraphy, Environ. Microbiol., 10, 1783-1803, 2008.

Crosbie, N. D., Pockl, M., and Weisse, T.: Dispersal and Phylogenetic Diversity of Nonmarine Picocyanobacteria, Inferred from 16S rRNA Gene and cpcBA-Intergenic Spacer Sequence Analyses, Appl. Environ. Microb., 69, 5716-5721, 2003

D’Abbadie, M., Hofreiter, M., Vaisman, A., Loakes, D., Gasparutto, D., Cadet, J., Woodgate, R, Pääbo, S., and Holliger, P.: Molecu- lar breeding of polymerases for amplification of ancient DNA Nature Biotechnol, 25, 939-943, 2007.

Dittrich, M., Kurz, P., and Wehrli, B.: The role of autotrophic picocyanobacteria in calcite precipitation in an oligotrophic lake, Geomicrobiol. J., 21, 45-53, 2004.

Disnar, J. R., Guillet, B., Keravis, D., Di-Giovanni, C., and Sebag, D.: Soil organic matter (SOM) characterization by Rock-Eval pyrolysis: Scope and limitations, Org Geochem, 34, 327-343, 2003.

Dokulil, M. T., Jagsch, A., George, G. D., Anneville, O., Jankowski, T., Wahl, B., Lenhart, B., Blenckner, T., and Teubner, K.: Twenty years of spatially coherent deepwater warming in lakes across Europe related to the North Atlantic Oscillation, Limnol. Oceanogr., 51, 2787-2793, 2006.

Dong, X., Bennion, H., Maberly, S. C., Sayer, C. D., Simpson, G. L., and Battarbee, R. W.: Nutrients exert a stronger control than climate on recent diatom communities in Esthwaite Water: evidence from monitoring and paleolimnological records, Freshwater Biol., 57, 2044-2056, doi:10.1111/j.13652427.2011.02670.x, 2012.

Dufresne, A., Salanoubat, M., Partensky, F., Artiguenave, F., Axmann, I.M., Barbe, V., Duprat, S., Galperin, M. Y., Koonin, E. V., Le Gall, F., Makarova, K. S., Ostrowski, M., Oztas, S., Robert, C., Rogozin, I. B., Scanlan, D. J., Tandeau de Marsac, N., Weissenbach, J., Wincker, P., Wolf, Y. I., and Hess, W. R.: Genome sequence of the cyanobacterium Prochlorococcus marinus SS120, a nearly minimal oxyphototrophic genome, P. Natl. Acad. Sci. USA, 100, 10020-10025, 2003.

Epp, L. S., Stoof K., Trauth M. H., and Tiedemann R.: Historical genetics on a sediment core from a Kenyan lake: Intraspecific genotype turnover in a tropical rotifer is related to past environmental changes, J. Paleolimnol., 43, 939-954, 2010.

Epp, L., Stoof-Leichsenring, K. R., Trauth, M. H., and Tiedemann, R.: Molecular profiling of diatom assemblages in tropical lake sediments using taxon-specific PCR and Denaturing High-Performance Liquid Chromatography (PCR-DHPLC), Mol. Ecol. Resour., 11, 842-853, 2011.

Ernst, S., Wollenzien, U. I. A., and Postius, C.: Ecosystemdependent adaptive radiations of picocyanobacteria inferred from 16S rRNA and ITS-1 sequence analysis, Microbiology, 149, 217-228, 2003.

Espitalié, J., Deroo, G., and Marquis, F. : La pyrolyse Rock-Eval et ses applications; première partie, Rev. I. Fr. Petr., 40, 563-579, 1985.

Fernández-Carazo, R., Hodgson, D. A., Convey, P., and Wilmotte, A.: Low cyanobacterial diversity in biotopes of the Transantarctic Mountains and Shackleton Range (80-82 $\left.{ }^{\circ} \mathrm{S}\right)$, Antarctica, FEMS Microbiol. Ecol., 77, 503-517, 2011.

Felföldi, T., Somogyi, B., Márialigeti, M., and Vörös, L.: Notes on the biogeography of non-marine planktonic picocyanobacteria: re-evaluating novelty, J. Plankton Res., 33, 1622-162, 2011.

Fogel, G. B., Collins, C. R., Li, J., and Brunk, C. F.: Prokaryotic genome size and SSU rDNA copy number: estimation of microbial relative abundance from a mixed population, Microb. Ecol., 38, 93-113, 1999.

Fu, F. X., Warner, M. E., Zhang, Y., Feng, Y., and Hutchins, D. A.: Effects of increased temperature and $\mathrm{CO}_{2}$ on photosynthesis,growth, and elemental ratios in marine Synechococcus and Prochlorococcus (Cyanobacteria), J. Phycol., 43, 485-496, 2007. 
Gaedke, U. and Weisse, T.: Seasonal and interannual variability of picocyanobacteria in Lake Constance (1987-1996), Arch. Hydrobiol., 53, 143-158, 1998.

Gerdeaux, D.: Does global warming threaten the dynamics of Arctic charr in Lake Geneva?, Hydrobiologia, 660, 69-78, 2011.

Gilbert, M. T. P., Bandlet, H. J., Hofreiter, M., and Barnes, I.: Assessing ancient DNA studies, Trends Ecol. Evol., 20, 541-544, 2005.

Giguet-Covex, C., Arnaud, F., Poulenard, J., Enters, D., Reyss, J. L., Millet, L., Lazzaroto, J., and Vidal, O.: Sedimentological and geochemical records of past trophic state and hypolimnetic anoxia in large, hard-water Lake Bourget, French Alps, J. Paleolimnol., 43, 171-190, 2010.

Groleau, A., Tassin, B., Paris, U., Marne, V. D., and Sarazin, G.: Calcite precipitation and interaction with phosphorus cycle in Lake Bourget (France), in: Geochemistry of the earth's surface, edited by: Ármannsson, H., Proceedings of the 5th International Symposium, Reykjavik, Iceland, 15-20 August 1999, 574 pp., 1999.

Hastie, T. and Tibshirani, R.: Generalized Additive Models, Stat Science, 1, 297-318, 1986.

Huber, T., Faulkner, G., and Hugenholtz, P.: Bellerophon; a program to detect chimeric sequences in multiple sequence alignments, Bioinformatics, 20, 2317-2319, 2004.

Hughes, J. B., Hellmann, J., Ricketts, T., and Bohannan, B. J. M.: Counting the uncountable: statistical approaches to estimating microbial diversity, Appl. Environ. Microb., 67, 4399-4406, 2001.

Iteman, I., Rippka, R., Tandeau de Marsac, N., and Herdman, M.: Comparison of conserved structural and regulatory domains within divergent 16S rRNA-23S rRNA spacer sequences of cyanobacteria, Microbiology, 146, 1275-1286, 2000.

Ivanikova, N. V., Linda, C., Popels, R., McKay, M. L., and Bullerjahn, G. S.: Lake Superior supports novel clusters of cyanobacterial picoplankton, Appl. Environ. Microb., 73, 4055-4065, 2007.

Janse, I., Meima, M., Kardinaal, W. E. A., and Zwart, G.: Highresolution differentiation of cyanobacteria by using rRNAinternal transcribed spacer denaturing gradient gen electrophoresis, Appl. Environ. Microb., 69, 6634-6643, 2003.

Jansson, M., Olsson, H., and Pettersson, K.: Phosphatase; origin, characteristics and function in lakes, Hydrobiologia, 170, 157$175,1988$.

Jardillier, L., Zubkov, M. W., Pearman, J., and Scanlan, D. J.: Significant $\mathrm{CO}_{2}$ fixation by small prymnesiophytes in the subtropical and tropical northeast Atlantic Ocean, ISME J., 4, 11801192, 2010.

Jasser, I., Krolicka, A., and Karnkowska-Ishikawa, A.: A novel phylogenetic clade of picocyanobacteria from the Mazurian lakes (Poland) reflects the early ontogeny of glacial lakes, FEMS Microbiol. Ecol., 75, 89-98, 2011.

Johnson, Z. I., Zinser, E. R., Coe, A., McNulty, N. P., Woodward, E. M. S., and Chisholm, S. W.: Niche partitioning among Prochlorococcus ecotypes along ocean-scale environmental gradients, Science, 311, 1737-1740, 2006.

Juggins, S.: C2 Version 1.7 User guide. Software for ecological and palaeoecological data analysis and visualisation, Newcastle upon Tyne, UK, 2007.

Jukes, T. H. and Cantor, C. R.: Evolution of protein molecules, in: Mammalian protein metabolism, edited by: Munro, H. N., Aca- demic Press, New York, 21-132, 1969.

Kamjunke, N., Straile, D., and Gaedke, U.: Response of heterotrophic bacteria, autotrophic picoplankton and heterotrophic nanoflagellates to re-oligotrophication, J. Plankton Res., 31, 899-907, 2009.

Katano, T., Kaneda, A., Takeoka, H., and Nakano, S.: Seasonal changes in the abundance and composition of picophytoplankton in relation to the occurrence of Kyucho and bottom intrusion in Uchiumi Bay, Japan, Mar. Ecol. Prog. Ser., 298, 59-67, 2005.

Kemp, P. F. and Aller, J. Y.: Estimating prokaryotic diversity: When are $16 \mathrm{~S}$ rDNA libraries large enough?, Limnol. Oceanogr.Meth., 2, 114-125, 2004.

Krishnaswami, S., Lal, D., Martin, J. M., and Meybeck, M.: Geochronology of lake sediments, Earth Planet. Sci. Lett., 11, 407-414, 1971.

Laurent, P. : Étude de la pollution du lac du Bourget, campagne 1969, Rapport Inra-Thonon, 16 pp., 1970.

Lozupone, C. and Knight, R.: UniFrac: a new phylo- genetic method for comparing microbial communities, Appl. Environ. Microb., 71, 8228-8235, 2005.

Marra, G. and Wood, S. N.: Practical variable selection for generalized additive models, Comput Stat Data An, 55, 2372-2387, 2011.

Matisoo-Smith, E., Roberts, K., Welikala, N., Tannock, G., Chester, P., Feek, D., and Flenley, J.: Recovery of DNA and pollen from New Zealand lake sediments, Quat. Int., 184, 139-149, 2007.

Martiny, J. B. H., Bohannan, B. J. M., Brown, J. H., Colwell, R. K., Fuhrman, J. A., Green J. L., Horner-Devine, M. C., Kane, M., Krumins, J. A., Kuske, C. R., Morin, P. J., Naeem, S., Øvreås, L., Reysenbach, A-L., Smith V. H., and Staley, J. T.: Microbial biogeography: Putting microorganisms on the map, Nat. Rev. Microbiol., 4, 102-112, 2006.

Mazard, S., Ostrowski, M., Partensky, F., and Scanlan, D.J.: Multilocus sequence analysis, taxonomic resolution and biogeography of marine Synechococcus, Environ. Microbiol., 14, 372-386, 2011.

Mazard, S., Wilson, W. H., and Scanlan, D. J.: Dissecting the physiological response to phosphorus stress in marine Synechococcus isolates (Cyanophyceae), J. Phycol., 48, 94-105, 2012.

Millet, L., Giguet-Covex, C., Verneaux, V., Druart, J. C., Adatte, T., and Arnaud, F. : Reconstruction of the recent history of a large deep prealpine lake (Lake Bourget, France) using subfossil chironomids, diatoms, and organic matter analysis: towards the definition of a lake-specific reference state, J. Paleolimnol., 44, 963-978, 2010.

Moutin, T., Thinsgtad, T. F., Van Wambeke, F., Marie, D., Slawyk, G., Raimbault, P., and Claustre, H.: Does competition for nanomolar phosphate supply explain the predominance of the cyanobacterium Synechococcus?, Limnol. Oceanogr., 47, 15621567, 2002.

Nei, M.: Molecular Evolutionary Genetics, New York, Columbia, p. 512, 1987.

Nolte, V., Pandey, R. V., Jost, S., Medinger, R., Ottenwalder, B., Boenigk, J., and Schlötterer, C.: Contrasting seasonal niche separation between rare and abundant taxa conceals the extent of protist diversity, Mol. Ecol., 19, 2908-2915, 2010.

Overpeck, J. T., Webb, T., and Prentice, I. C.: Quantitative interpretation of fossil pollen spectra: Dissimilarity coefficients and the method of modern analogs, Quat. Res., 23, 87-108, 1985. 
Palenik, B., Brahamsha, B., Larimer, F. W., Land, M., Hauser, L., Chain, P., Lamerdin, J., Regala, W., Allen, E. E., McCarren, J., Paulsen, I., Dufresne, A., Partensky, F., Webb, E. A., and Waterbury J.: The genome of a motile marine Synechococcus, Nature, 424, 1037-1042, 2003.

Palenik B., Ren Q. H., Dupont C. L., Myers G. S., Heidelberg J. F., Badger J. H., Madupu R., Nelson W. C., Brinkac, L. M., Dodson, R. J., Durkin, A. S., Daugherty, S. C., Sullivan, S. A., Khouri, Y., Mohamoud, Y., Halpin, R., and Paulsen, I. T.: Genome sequence of Synechococcus CC9311, insights into adaptation to a coastal environment, P. Natl. Acad. Sci. USA, 103, 13555-13559, 2006.

Panieri, G., Lugli, S., Manzi, V., Roveri, M., Schreiber, B. C., and Palinska, K. A.: Ribosomal RNA gene fragments from fossilized cyanobacteria identified in primary gypsum from the late Miocene, Italy, Geobiology, 8, 101-111, 2010.

Personnic, S., Domaizon, I., Sime-Ngando, T., and Jacquet, S.: Seasonal variations of microbial abundances and virus- vs. flagellate-induced mortality of picoplankton in three peri-alpine lakes, J. Plankton Res., 31, 1161-1177, 2009.

Pitt, F. D., Mazard, S., Humphreys, L., and Scanlan, D. J.: Functional Characterization of Synechocystis sp. Strain PCC 6803 pst1 and pst2 Gene Clusters Reveals a Novel Strategy for Phosphate Uptake in a Freshwater Cyanobacterium. J Bacteriol., 192, 3512-3523, 2010.

Postius, C. and Ernst, A.: Mechanisms of dominance: coexistence of picocyanobacterial genotypes in a freshwater ecosystem, Arch. Microbiol., 172, 69-75, 1999.

R Development Core Team: R: A language and environment for statistical computing, R Foundation for Statistical Computing, Vienna, Austria, ISBN 3-900051-07-0, http://www.R-project.org, 2008.

Reyss, J. L., Schimdt, S., Legeleux, F., and Bonte, P.: Large low background well type detectors for measurements of environmental radioactivity, Nucl. Instrum. Methods A, 357, 391-397, 1995.

Rippka, R.: Isolation and purification of cyanobacteria, in: Metods in enzymology, edited by: Packer, L. and Glazer, A. N., Cyanobacteria, Academic Press New York, USA, 167, 3-28, 1998.

Robertson, B. R., Tezuka, N., and Watanabe, M. M.: Phylogenetic analyses of Synechococcus strains (cyanobacteria) using sequences of $16 \mathrm{~S}$ rDNA and part of the phycocyanon operon reveal multiple evolutionary lines and reflect phycobilin content, Int. J. Syst. Evol. Micr., 51, 861-871, 2001.

Rocap, G., Larimer, F. W., Lamerdin, J., Malfatti, S., Chain, P., Ahlgren, N. A., Arellano, A., Coleman, M., Hauser, L., Hess, W. R., Johnson, Z. I., Land, M., Lindell, D., Post, A. F., Regala, W., Shah, M., Shaw, S. L., Steglich, C., Sullivan, M. B., Ting, C. S., Tolonen, A., Webb, E. A., Zinser, E. R., and Chisholm, S. W.: Genome divergence in two Prochlorococcus ecotypes reflects oceanic niche differentiation, Nature, 424, 1042-1047, 2003.

Ruggiu, D., Morabito, G., Panzani, P., and Pugnetti, A.: Trends and relations among basic phytoplankton characteristics in the course of the long-term oligotrophication of Lago Maggiore, in: Phytoplankton and trophic gradients, edited by: Alvarez-Cobelas, M., Reynolds, S., Sanchez-Castillo, P. and Kristiansen, J., Kluwer Academic Publisher, Hydrobiologia, 369/370, 243-257, 1998.

Sanchez-Baracaldo, P., Handley, B. A., and Hayest, P. K.: Picocyanobacterial Community Structure of Freshwater Lakes and the Baltic Sea Revealed by Phylogenetic Analyses and CladeSpecific Quantitative PCR, Microbiology, 154, 3347-3357, 2008.

Savichtcheva, O., Debroas, D., Kurmayer, R., Villar, C., Jenny, J. P., Arnaud, F., Perga, M. E., and Domaizon, I.: Quantitative PCR enumeration of total/toxic Planktothrix rubescens and total Cyanobacteria in preserveed DNA isolated from lake sediments, Appl. Environ. Microbiol., 77, 8744-8753, 2011.

Savichtcheva, O., Debroas, D., Perga, M. E., Arnaud, F., Villar, C., Jenny, J. P., and Domaizon, I.: Diversity and dynamics of cyanobacteria inferred from sediment DNA: focus on Planktothrix rubescens in re-oligotrophicated Lake Bourget, in preparation, 2013.

Schloss, P. D. and Handelsman, J.: Introducing DOTUR, a computer program for defining operational taxonomic units and estimating species richness, Appl. Environ. Microb., 71, 1501-1506, 2005.

Scovhus, T. L., Ramsing, N. B., Holmstrom, C., Kjelleberg, S., and Dahllof, I.: Real-time quantitative PCR for assessment of abundance of Pseudoalteromonas species in marine samples, Appl. Environ. Microb., 70, 2373-2382, 2004.

Simpson, G. L. and Anderson, N. J.: Deciphering the effect of climate change and separating the influence of confounding factors in sediment core records using additive models, Limnol. Oceanogr., 54, 2529-2541, 2009.

Stockner, J., Callieri, C., and Cronberg, G.: Picoplankton and other non-bloom forming cyanobacteria in lakes, in: The Ecology of Cyano-bacteria. Their Diversity in Time and Space, edited by: Whitton, B. A. and Potts, M., Kluwer Academic Publishers, Dordrecht, the Netherlands, 195-238, 2000.

Stoof-Leichsenring, K. R., Epp, L., Trauth, M. H., and Tiedemann, R.: Hidden diversity in diatoms of Kenyan Lake Naivasha: a genetic approach detects temporal variation, Mol. Ecol., 21, 19181930, 2012.

Tamura, K., Peterson, D., Peterson, N., Stecher, G., Nei, M., and Kumar, S.: MEGA5: Molecular Evolutionary Genetics Analysis using Maximum Likelihood, Evolutionary Distance, and Maximum Parsimony Methods, Mol. Biol. Evol., 28, 2731-2739, 2011.

Tao, M., Xie, P., Chen, J., Qin, B., Zhang, D., Niu, Y., Zhang, M., Wang, Q., and Wu, L.: Use of a Generalized Additive Model to Investigate Key Abiotic Factors Affecting Microcystin Cellular Quotas in Heavy Bloom Areas of Lake Taihu, PLoS ONE, 7, e32020, doi:10.1371/journal.pone.0032020, 2012.

Ter Braak, C. J. F. and Juggins, S.: Weigthed averaging partial least squares regression (WA-PLS): an improved method for reconstructing environmental variables from species assemblages, Hydrobiologia, 269, 485-502, 1993.

Ter Braak, C. J. F. and Van Dame, H.: Inferring pH from diatoms: a comparison of old and new calibration methods, Hydrobiologia, 178, 209-223, 1989.

Thompson, J. D., Higgins, D. G., and Gibson, T. J.: CLUSTAL W: improving the sensitivity of progressive multiple sequence alignment through sequence weighting, position-specific gap penalties and weight matrix choice, Nucleic. Acids. Res., 22, 46734680, 1994.

Urbach, E., Scanlan, D. J., Distel, D. L., Waterbury, J. B, and Chisholm, S. W.: Rapid Diversification of Marine Picophytoplankton with Dissimilar Light-Harvesting Structures Inferred from Sequences of Prochlorococcus and Synechococcus 
(Cyanobacteria), J. Mol. Evol., 46, 557-572, 1998.

Vadstein, O.: Heterotrophic, planktonic bacteria and cycling of phosphorus: phosphorus requirements, competitive ability and food web interactions. Adv Microb Ecol, 16, 115-168, 2000.

Vaitomaa, J., Rantala, A., Halinen, K., Rouhiainen, L., Tallberg, P., Mokelke, L., and Sivonen, K.: Quantitative real-time PCR for determination of microcystin synthetase E copy numbers for Microcystis and Anabaena in lakes, Appl. Environ. Microb., 69, 72897297, 2003.

Van Mooy, B. A., Rocap, G., Fredricks, H. F., Evans, C. T., and Devol, A. H.: Sulfolipids dramatically decrease phosphorus demand by picocyanobacteria in oligotrophic marine environments, P. Natl. Acad. Sci. USA, 103, 8607-8612, 2006.

Wilhelm, S. W., Bullerjahn, G. S., Eldridge, M. L., Rinta-Kanto, J. M., and Bourbonniere, R. A.: Seasonal hypoxia and the genetic diversity of prokaryote populations in the central basin hypolimnion of Lake Erie : evidence for abundant cyanobacteria and photosynthesis, J. Great Lakes Res., 32, 657-671, 2006.

Willerslev, E., Cappellini, E., Boomsma, W.,Nielsen, R., Hebsgaard, M.B., Brand, T. B., Hofreiter, M., Bunce, M., Poinar, H. N., Dahl-Jensen, D., Johnsen, S., Steffensen, J. P., Bennike, O., Schwenninger, J-L., Nathan, R., Armitage, S., de Hoog, CJ., Alfimov, V., Christl, M., Beer, J., Muscheler, R., Barker, J., Sharp, M., Penkman, K. E. H., Haile, J., Taberlet, P., Gilbert, M. T. P., Casoli, A., Campani, E., and Collins, M. J.: Ancient Biomolecules from Deep Ice Cores Reveal a Forested Southern Greenland, Science, 317, 111-114, 2007.
Wilmotte, A.: Molecular evolution and taxonomy of the Cyanobacteria. In: Bryant, D. A. The Molecular Biology of Cyanobacteria, Kluwer Academic, Dordrecht, 1-25, 1994.

Wilmotte, A. and Herdman, M.: Phylogenetic relationships among the cyanobacteria based on 16S rDNA sequences, Manual of Systematic Bacteriology, Bergey's Manual of Systematic Bacteriology, edited by: Garrity, G. M., Boone, D. R., Castenholz, R. W., Springer New York, USA, 487-493, 2001.

Wood, S. N.: Generalized Additive Models: An Introduction with R. Chapman and Hall Boca Raton, FL, USA, 2006.

Wu, Q. L., Xing, P., and Liu, W. T.: East Tibetan lakes harbour novel clusters of picocyanobacteria as inferred from the 16S-23S rRNA internal transcribed spacer sequences, Microb. Ecol., 59, 614-622, 2010.

Wunsam, S. and Schmidt, R.: A diatom-phoshprus trasnfer function for alpine and pre-alpine lakes. Memorie dell'Instituto Italiano di Idrobiologia, 53, 85-99, 1995.

Zolitschka, B.: Dating based on freshwater and marine laminated sediments. In: Global change in the Holocene, edited by: Mackay, A., Battarbee, R., Birks, J., Oldfield, F., Edward Arnold Publishers, London, 92-106, 2003.

Zwirglmaier, K., Jardillier, L., Ostrowski, M., Mazard, S., Garczarek, L., Vaulot, D., Not, F., Massana, R., Ulloa, O., and Scanlan, D. J.: Global phylogeography of marine Synechococcus and Prochlorococcus reveals a distinct partitioning of lineages amongst oceanic biomes, Environ. Microbiol., 10, 147$161,2008$. 